\title{
BMP type II receptor as a therapeutic target in pulmonary arterial hypertension
}

\author{
Mar Orriols $^{1} \cdot$ Maria Catalina Gomez-Puerto $^{1} \cdot$ Peter ten Dijke $^{1}$
}

Received: 22 December 2016 / Revised: 9 March 2017 / Accepted: 17 March 2017 / Published online: 26 April 2017

(C) The Author(s) 2017. This article is an open access publication

\begin{abstract}
Pulmonary arterial hypertension (PAH) is a chronic disease characterized by a progressive elevation in mean pulmonary arterial pressure. This occurs due to abnormal remodeling of small peripheral lung vasculature resulting in progressive occlusion of the artery lumen that eventually causes right heart failure and death. The most common cause of PAH is inactivating mutations in the gene encoding a bone morphogenetic protein type II receptor (BMPRII). Current therapeutic options for PAH are limited and focused mainly on reversal of pulmonary vasoconstriction and proliferation of vascular cells. Although these treatments can relieve disease symptoms, PAH remains a progressive lethal disease. Emerging data suggest that restoration of BMPRII signaling in PAH is a promising alternative that could prevent and reverse pulmonary vascular remodeling. Here we will focus on recent advances in rescuing BMPRII expression, function or signaling to prevent and reverse pulmonary vascular remodeling in PAH and its feasibility for clinical translation. Furthermore, we summarize the role of described miRNAs that directly target the BMPR2 gene in blood vessels. We discuss the therapeutic potential and the limitations of promising new approaches to restore BMPRII signaling in PAH patients. Different mutations in $B M P R 2$ and environmental/genetic factors make PAH a heterogeneous disease and it is thus likely that the best approach will be patient-tailored therapies.
\end{abstract}

Mar Orriols and Maria Catalina Gomez-Puerto the authors have contributed equally to this work.

Peter ten Dijke

p.ten_dijke@lumc.nl

1 Department of Molecular Cell Biology and Cancer Genomics Center Netherlands, Leiden University Medical Center, Leiden, The Netherlands
Keywords Endothelial cell - Vascular smooth muscle cell $\cdot$ Signal transduction $\cdot$ Inflammation $\cdot$ Vascular remodeling and autophagy
Abbreviations
ACE Angiotensin-converting enzyme
ACVRII Activin type II receptor type
ACVRL1 Gene encoding activin receptor-like kinase
ALK Activin receptor-like kinase
BMP Bone morphogenetic protein
BMPRI Bone morphogenetic protein type I receptor
BMPRII Bone morphogenetic protein type II receptor
BMPR2 Gene encoding bone morphogenetic protein receptor II
Cav1 Caveolin-1
cGMP Cyclic guanosine monophosphate
DN Dominant negative
EC Endothelial cell
EndMT Endothelial-to-mesenchymal transition
FKBP12 FK-binding protein-12
GDF Growth and differentiation factor
GDF-2 Gene encoding BMP9
HMGA1 High-mobility group protein
iTOP Induced transduction by osmocytosis and propanebetaine
MCT Monocrotaline
mPAP Mean pulmonary arterial pressure
miRNA MicroRNA
NMD Non-sense mediated decay
PAEC Pulmonary arterial endothelial cells
PAH Pulmonary arterial hypertension
PASMC Pulmonary arterial smooth muscle cells
$\mathrm{PGI}_{2} \quad$ Prostacyclin
PKG Protein kinase $\mathrm{G}$
PTC Premature termination codon 


$\begin{array}{ll}\text { RV } & \text { Right ventricle } \\ \text { SMC } & \text { Smooth muscle cell } \\ \text { TGF- } \beta & \text { Transforming growth factor-beta } \\ \text { TNF } \alpha & \text { Tumor necrosis factor-alfa }\end{array}$

\section{Introduction}

Pulmonary arterial hypertension (PAH) is a chronic disease characterized by a progressive elevation in mean pulmonary arterial pressure (mPAP $>25 \mathrm{mmHg}$ ) leading to right heart failure and death [1]. PAH is characterized by abnormal remodeling of small peripheral lung vasculature resulting in progressive occlusion of the artery lumen. In addition, at late stages, so-called plexiform lesions are found, which are complex vascular formations originating from abnormal endothelial cell (EC) proliferation and vascular smooth muscle cell (SMC) hypertrophy [2]. The basic pathogenic mechanisms underlying this disease include vasoconstriction, intimal proliferation, and medial hypertrophy. These processes are accompanied by illicit recruitment of inflammatory cells which release factors enhancing cell proliferation and elastin fibers degradation $[3,4]$ (Fig. 1).

More than $70 \%$ of patients with familial PAH and $20 \%$ of idiopathic PAH show heterozygous mutations in the bone morphogenetic protein type II receptor (BMPRII) [5-8]. BMPRII is a transmembrane serine/threonine kinase receptor of the bone morphogenetic protein (BMP) pathway which is essential for embryogenesis, development, and adult tissue homeostasis. Upon BMP-induced heteromeric complex formation of BMPRII with BMP type I receptor (BMPRI), BMPRII activates BMPRI by phosphorylation. Thereafter, the activated BMPRI propagates the signal into the cell through phosphorylation of the SMAD1/5/8 transcription factors.

In $\mathrm{PAH}$, over 300 mutations have been found in the BMPR2 gene. These mutations target sequences that encode the ligand binding and kinase domain and the long cytoplasmic tail; the mutations compromise BMPRII function [9]. Although the BMPRII pathway is essential for vascular homeostasis and there is a strong correlation between $B M P R 2$ mutations and $\mathrm{PAH}$, the incomplete penetrance of BMPRII mutations (20-30\%) suggests that other genetic and environmental factors contribute to the disease. Among them, $B M P R 2$ alternative splicing plays a role in PAH penetrance. One BMPR2 splice variant lacks exon 12 , which is the largest exon of the gene and encodes the cytoplasmic tail. It has been shown that carriers of this variant are more prone to develop PAH through a dominant-negative effect (DN) effect on wild-type BMPRII [10]. Furthermore, there are mutations in other genes in the BMP pathway, which further strengthens the notion of a causal

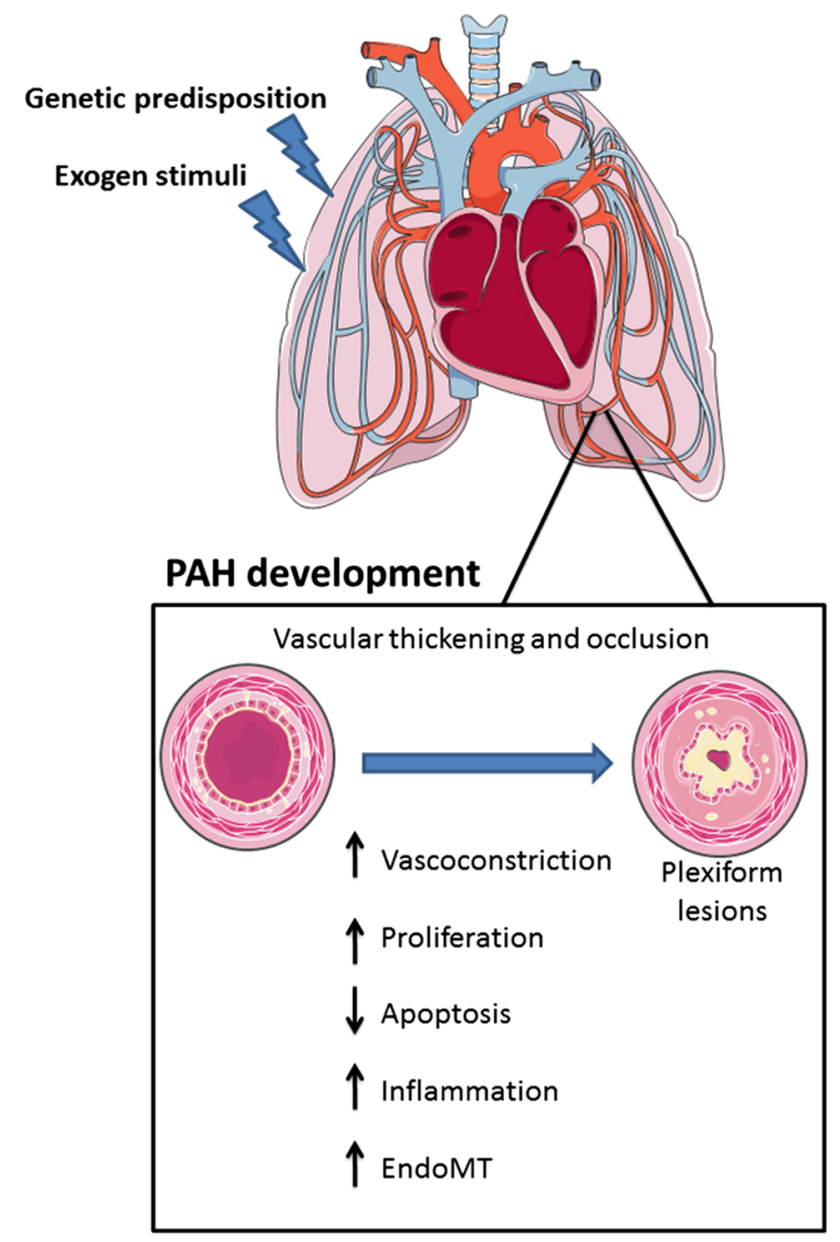

Fig. 1 Physiopathological mechanisms of pulmonary arterial hypertension development. Presence of genetic risk factors such as $B M P R 2$ mutations together with exposure to deleterious environmental or biological stimuli in the lung promotes PAH. PAH development is characterized by a disturbance on the signaling pathways that control pulmonary vascular homeostasis. It results in pulmonary vascular thickening and occlusion compromising lung and heart function. EndMT endothelial-to-mesenchymal transition

role for this pathway in PAH [11]. Moreover, the co-existence of modifier genes, infections, toxic exposure, inflammation, or alterations in estrogen metabolism has been described [11-14] and some of them were found to downregulate BMPRII expression. For example, pro-inflammatory cytokines such as tumor necrosis factor $\alpha(\mathrm{TNF} \alpha)$ and Interleukin 6 induce the expression of miRNAs that inhibit BMPRII expression [15]. Furthermore, BMPRII is essential for maintaining the barrier function of the pulmonary artery endothelial cell lining and BMPRII deficiency increases endothelial inflammatory responses thereby contributing to adverse vascular remodeling [16-18].

Current therapeutic options for PAH are limited and focused mainly on reversal of pulmonary vasoconstriction and proliferation of vascular cells through targeting of 
prostacyclin $\left(\mathrm{PGI}_{2}\right)$, endothelin, or nitric oxide pathways [19]. Although these treatments can relieve disease symptoms and slow down its progression, PAH remains a progressive lethal disease. Abundant research over the past decade has improved our understanding of the molecular mechanisms underlying PAH progression revealing novel potential therapeutic interventions [20-22]. Among them there are several anti-proliferative strategies including cell cycle inhibitors (e.g., mTOR inhibitor rapamycin) and anti-apoptotic drugs (e.g., surviving inhibitors) [23]. Furthermore, based on the fact that Rho and ROCK mediate smooth muscle cell proliferation in a serotonin-BMPRdependent pathway, Rho-kinase inhibitors have been also considered [23, 24]. Although several drugs with possible benefit in PAH have been identified, only very few have been approved for use in the clinic due to toxicity or lack of clinical efficacy. This review will focus on recent advances on the rescue of BMPRII expression, function, or signaling to prevent and reverse pulmonary vascular remodeling in PAH. We will discuss data on the in vitro efficacy of the different approaches together with the physiological outcomes in pre-clinical models and their feasibility for clinical translation.

\section{BMP signaling in vascular biology and PAH}

BMPs belong to the multifunctional transforming growth factor- $\beta$ (TGF- $\beta$ ) family of secreted dimeric cytokines. The effects of BMPs are highly dependent on cellular context [25]. In general, BMPs control cellular proliferation, differentiation, and apoptosis, and play an important role in embryonic development and maintaining tissue homeostasis [26]. Therefore, perturbation of BMP signaling may lead to skeletal diseases, vascular diseases, and cancer [27]. BMPs can be subdivided into four subgroups based on their sequence similarity and cell surface receptor affinities: BMP2/4, BMP5/6/7/8, BMP9/10, and growth and differentiation factor (GDF)-5/6/7 [28, 29]. BMPs signal via hetero-tetrameric combinations of type I receptors (activin receptor-like kinase (ALK)1, ALK2, ALK3, or ALK6) and BMP type II receptors (BMPRII) and activin type II receptor (ACVRII)A or ACVRIIB complexes [30, 31]. Both, type I and type II receptors have a similar structure encompassing a short extracellular domain, a single transmembrane domain and an intracellular domain with intrinsic serine-threonine kinase activity. In the vascular endothelium, BMP signaling is mainly activated by BMP2, $4,6,9$, and 10 [32]. BMP2 and BMP4 bind preferentially to the BMPRII in complex with ALK3 or ALK6. BMP6 binds to the ACVRIIA-ALK2 complex, while BMP9 and BMP10 bind to BMPRII or ACVRII in combination with ALK1 or ALK2. Whereas BMPRII is a specific receptor for BMPs,
ACVRIIA and ACVRIIB can also interact functionally with other ligands, such as activins, myostatin, and nodal. Interestingly, ALK2 and 6 are widely expressed in various cell types, while ALK1 has a more selective expression pattern and is mainly restricted to ECs. After BMP binding and receptor complex formation, the type II receptor kinase phosphorylates the type I receptor on serine and threonine residues in the glycine-serine rich (GS)-domain causing its activation and subsequent phosphorylation of the receptor-associated R-SMAD1, 5, and 8 effector proteins. The R-SMADs that are activated by TGF- $\beta$ type I and activin type I receptor (i.e., ALK5 and ALK4, respectively) are SMAD2 and SMAD3 and these are distinct from BMP R-SMADs. Activated R-SMAD 1, 5, or 8 forms a heterooligomeric complex with common mediator co-SMAD4. This complex translocates to the nucleus and regulates the expression of target genes by binding to specific enhancers/promoters upstream of these target genes [30, 33, 34] (Fig. 2). Besides canonical BMP receptor/SMAD signaling, activated BMP receptors can initiate non-SMAD signaling pathways such as ERK, JNK, p38 MAP kinases, and the phosphatidyl inositol 3 kinase (PI3K)/AKT pathways [35-37]. These non-SMAD pathways are also important for diversifying and modulating the canonical SMAD signaling pathways that are activated by the BMP receptors [38, 39]. In addition, BMP activity is also regulated by several extracellular modulators, including BMP binding proteins NOGGIN, CHORDIN, and FIBULINs. Co-receptors such as ENDOGLIN, BETAGLYCAN, and DRAGON family members may also modulate the interactions between BMPs and BMP receptors [40, 41]. Moreover, intracellular kinases/phosphatases and other binding proteins have been identified as regulators of the trafficking, subcellular localization, stability, and function of BMP receptors and SMADs [26].

Genetic depletion of different components of the BMP signaling cascade leads to embryonic death due to cardiovascular malformations and abnormal vascular remodeling. BMP signaling plays an important role in vasculogenesis (de novo formation of blood vessels from undifferentiated mesodermal cells) and angiogenesis (formation of new blood vessels from the existing vasculature). In this light, it is not surprising to discover that, besides PAH, dysfunction of BMP signaling has been found to be associated with other vascular diseases including hereditary hemorrhagic telangiectasia, cerebral cavernous malformation, atherosclerosis, and vascular calcification among others [42]. Furthermore, BMPRII downregulation has been found to be involved in pancreatic and lung fibrosis [43, 44].

Blood vessels are composed of three layers: the tunica adventitia consisting of fibroblasts and associated collagen fibers; the tunica media composed of SMCs; and the tunica intima consisting of ECs coating the interior surface [45, 
Fig. 2 BMP signaling in endothelial cells. BMP9 and BMP10 present in the circulation initiate signaling by binding and bringing together BMPRII and ALK1. BMPRII phosphorylates ALK1 which then propagate the signal through phosphorylation of SMAD1/5/8. Subsequently, SMAD4 forms a complex with SMAD1/5/8, which translocates to the nucleus regulating the expression of target genes such as ID1 and ID3. Known gene mutations associated with PAH are highlighted in red. It includes mutations in BMP signaling components $(G D F 2$, $B M P R 2, A L K 1$, SMAD8, and ENDOGLIN) as well as recently discovered non-directly related BMP genes (CAV1, KCNK3, and EIF2AK4). CAV caveolin, EFI2AK4 eukaryotic translation initiation factor $2 \alpha$ kinase 4 , $E N G$ ENDOGLIN, ID inhibitor of DNA binding, $K C N K 3$ potassium channel subfamily $\mathrm{K}$ member 3

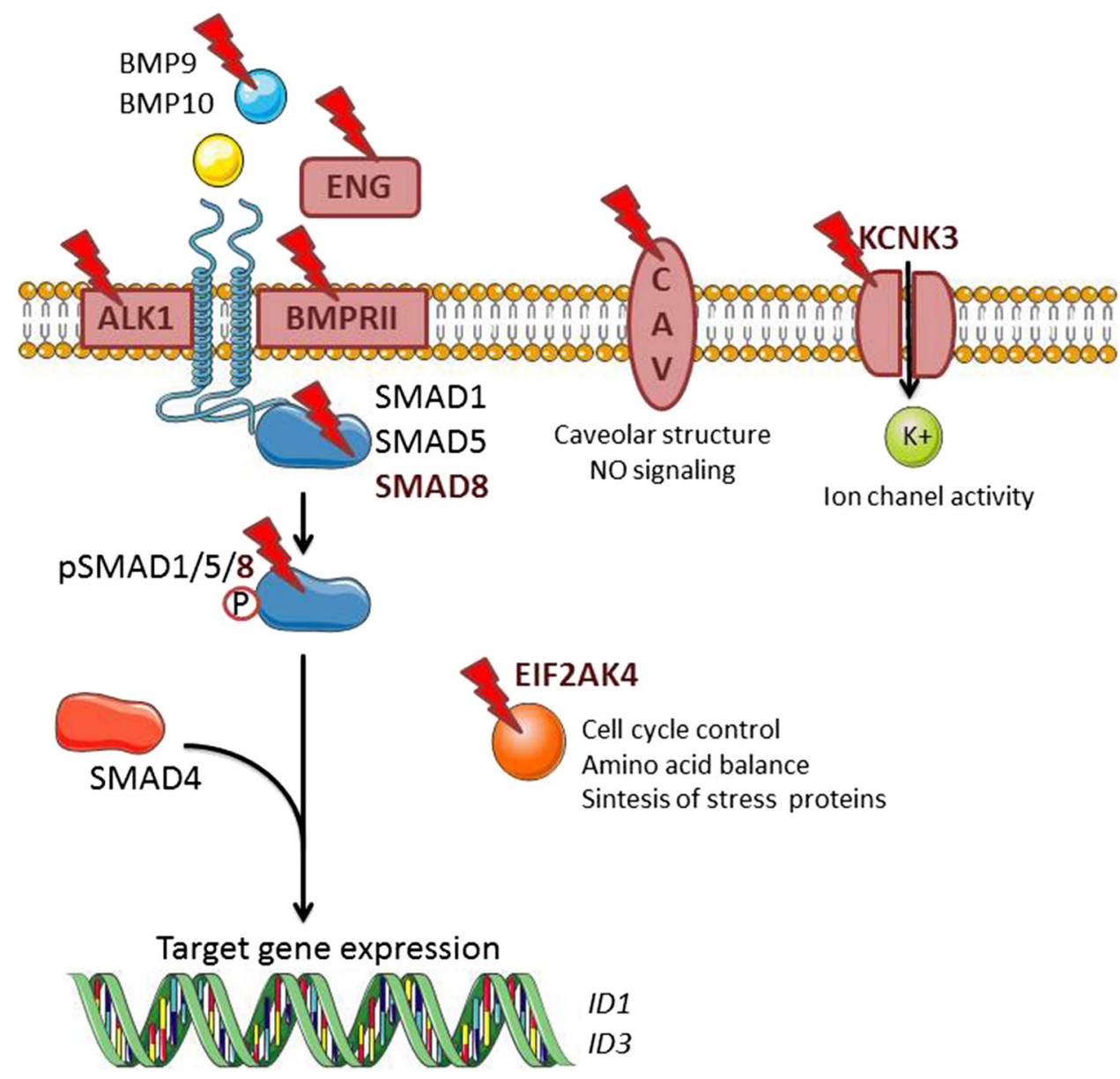

46]. ECs, SMCs, and fibroblasts have been found to play a role in the pathogenesis of PAH. Abnormal EC proliferation resulting in the formation of plexiform lesions has been frequently described in many PAH cases [47]. In addition, pulmonary arterial SMCs show an increased proliferation and decreased apoptosis leading to vessel wall thickening and vascular remodeling (Fig. 1). The close interaction between ECs and SMCs has been found to be involved in vessel formation and maintenance. For instance, endothelial derived factors, like endothelin and angiotensin II, affect SMCs which increases vascular tone. Similarly, nitric oxide and $\mathrm{PGI}_{2}$ secreted by ECs modulate the vasodilator response of SMCs [48]. In particular, $\mathrm{PGI}_{2}$ has been found to be reduced in PAH patients [49].

BMP signaling is known to control cell migration, proliferation, and apoptosis in ECs and SMCs [45]. BMP9 and BMP10 are present in the circulation and play an important role in the vasculature. Their associated receptors BMPRII and ALK1 and co-receptor ENDOGLIN are predominantly expressed on ECs $[50,51]$ and together can modulate the ability of ECs to migrate and proliferate [27]. Furthermore, BMPRII is also expressed in vascular SMCs where it has been shown to be necessary for the control of proliferation and differentiation [52]. Besides mutations in the BMPR2 gene, mutations in the genes of other BMP signaling components (such as GDF-2, ACVRL1, ENDOGLIN, and SMAD8) have also been linked to PAH development [11, 53-59]. This association reinforces the importance of BMP signaling in the control of vascular homeostasis, and suggests that there is a causal link between perturbation of canonical BMP/SMAD signaling and PAH. In support of this view, recent, new DNA sequencing techniques helped to identify new gene mutations associated to PAH [Caveolin-1 (CAV1), KCNK3, and EIF2AK4] [60, 61] (Fig. 2).

The abnormal vascular remodeling that characterizes PAH involves an accumulation of $\alpha$-smooth muscle, actin-expressing mesenchymal-like cells indicating that the endothelial-to-mesenchymal transition (EndMT) may be involved in the pathogenesis of the disease [62]. In addition, BMPRII reduction in pulmonary artery endothelial cells (PAECs) has been found to promote the trans-differentiation of epithelial cells into motile mesenchymal cells via the transcription factors high-mobility group protein (HMGA)1 and its target SLUG [63]. 


\section{Animal models of PAH}

PAH has a complex etiology and pathobiology with many factors contributing to its development [64]. A variety of pre-clinical rodent models have been used to study the underlying pathophysiological mechanisms and to test novel therapeutic strategies for PAH. A proper model should be reproducible, inexpensive, and faithfully reproduce (in a defined period) the basic features of PAH such as complex destructive neointimal lesions and right ventricle (RV) dysfunction and failure. To date, there is no model that recapitulates all of the pathophysiological mechanisms and the clinical course of human PAH. For instance, in the chronic hypoxic exposure or monocrotaline (MCT)induced rat models, pulmonary hypertension rarely develops with the same severity observed in humans perhaps due to the absence of obstructive intimal lesions in the peripheral pulmonary arteries $[65,66]$. Furthermore, the chronic hypoxia model does not lead to RV failure, while MCT injection causes myocarditis affecting both ventricles and causing liver and kidney damage [67]. These limitations may explain why it is difficult to translate the reversal of PAH in animal models by several experimental compounds into therapies for PAH patients.

In recent years, second-generation animal models have been established based on the combination of multiple triggers: MCT plus pneumonectomy, MCT plus chronic hypoxia, and SU5416 plus chronic hypoxia. To circumvent the problem of the embryonic lethality of BMPR2 knockout mice, switchable rodent models have been developed, by means of $B M P R 2$ conditional knock-out, whereby the mutation can be activated after birth [68-70]. Moreover, genetic rodent models have been developed including overexpression of interleukin-6. These new models closely mimic the features and the severity of human PAH although not completely [71]).

\section{Restoring BMPRII signaling as a therapeutic strategy}

While hereditary PAH have been linked to heterozygous mutations in the BMPR2 gene, non-genetic forms of PAH show a reduction in BMPRII levels and activity [9]. Consistent with this, heterozygous $B M P R 2$ deletion in PAECs and pulmonary artery smooth muscle cells (PASMCs) mimics the PAH phenotype $[69,72]$. Furthermore, mice expressing a dominant-negative BMPRII (lacking an intracellular domain) in vascular SMC, develop vascular lesions in the lungs $[68,72]$.

There is strong evidence suggesting that BMPRII signaling has a protective role in the vascular wall by promoting the survival of PAECs, inhibiting PASMCs proliferation and triggering anti-inflammatory responses [17, 73, 74]. Based on this, modulation of BMPRII signaling is considered a promising therapeutic approach for PAH. Importantly, the rescue of BMPRII expression may not exclusively benefit PAH patients but also patients suffering from pancreatic and lung fibrosis where BMPRII deficiency has been implicated [43, 44]. BMPRII restoration can be targeted at different levels: genetic-based therapies, transcriptional and translational regulation, protein activity, and processing as well as SMAD downstream signaling modulation [27, 75, 76] (Fig. 3).

\section{Genetic-based therapies}

\section{Exogenous BMPR2 gene delivery}

One strategy to treat PAH patients is to rescue BMPRII expression through gene therapy targeting ECs. In preclinical models, this was explored by Reynolds et al., who administrated a vector inducing BMPRII expression via tail-vein injection. The $B M P R 2$ encoding virus targets the pulmonary endothelium by binding to the highly expressed pulmonary endothelial angiotensin-converting enzyme (ACE) using a bi-specific conjugate antibody. This BMPR2 adenoviral vector restored BMPRII protein levels in human microvascular PAECs and attenuated the PAH phenotype in a chronic hypoxia model and MCT-treated rats [77, 78]. Furthermore, BMPRII overexpression in lung tissue was shown to reverse the imbalance between BMPRII and TGF $\beta$ signaling thus restoring normal levels of pSMAD $1 / 5 / 8$ and the activation of PI3K and p38 MAP kinase [79]. In contrast, BMPRII administration via an aerosol route targeting PASMCs did not improve the PAH phenotype when tested in the MCT model [80]. The later result highlights the importance of BMPRII signaling in ECs but not SMCs. However, further investigations will be required to elucidate precisely how spatio-temporal control BMPRII overexpression might provide therapeutic benefit in the context of $B M P R 2$ mutations. It should be noted that adenoviral vectors are only capable of transient gene expression since the delivered gene is not integrated into the host chromosome. Stable integration can be achieved and lentiviral vectors are potentially an attractive vehicle to deliver longer term transgene expression since they integrate into the genome and they can infect non-proliferating cells, when compared to retroviral vectors. An important potential limitation of this approach is that integrating vectors may generate gene mutations upon insertion and newer advances regarding self-inactivating vectors are needed [81, 82]. Adeno-associated virus and helper dependent adenoviral vectors (the latest generation of recombinant adenoviral vectors) are a promising alternative since they deliver longer durations of transgene expression when compared 
Fig. 3 Rescuing the BMPRII signaling pathway in pulmonary arterial hypertension. Modulation of BMPRII signaling is considered a promising therapeutic approach for PAH. This could be achieved by different methods aiming to increase the amounts of BMPRII present in the cell or to trigger BMP signaling. These approaches include exogenous BMPRII delivery, inhibition of miRNAs negatively regulating BMPRII stability and translation, inhibition of lysosomal degradation, and delivery of exogenous BMP ligands or BMP coactivators among others

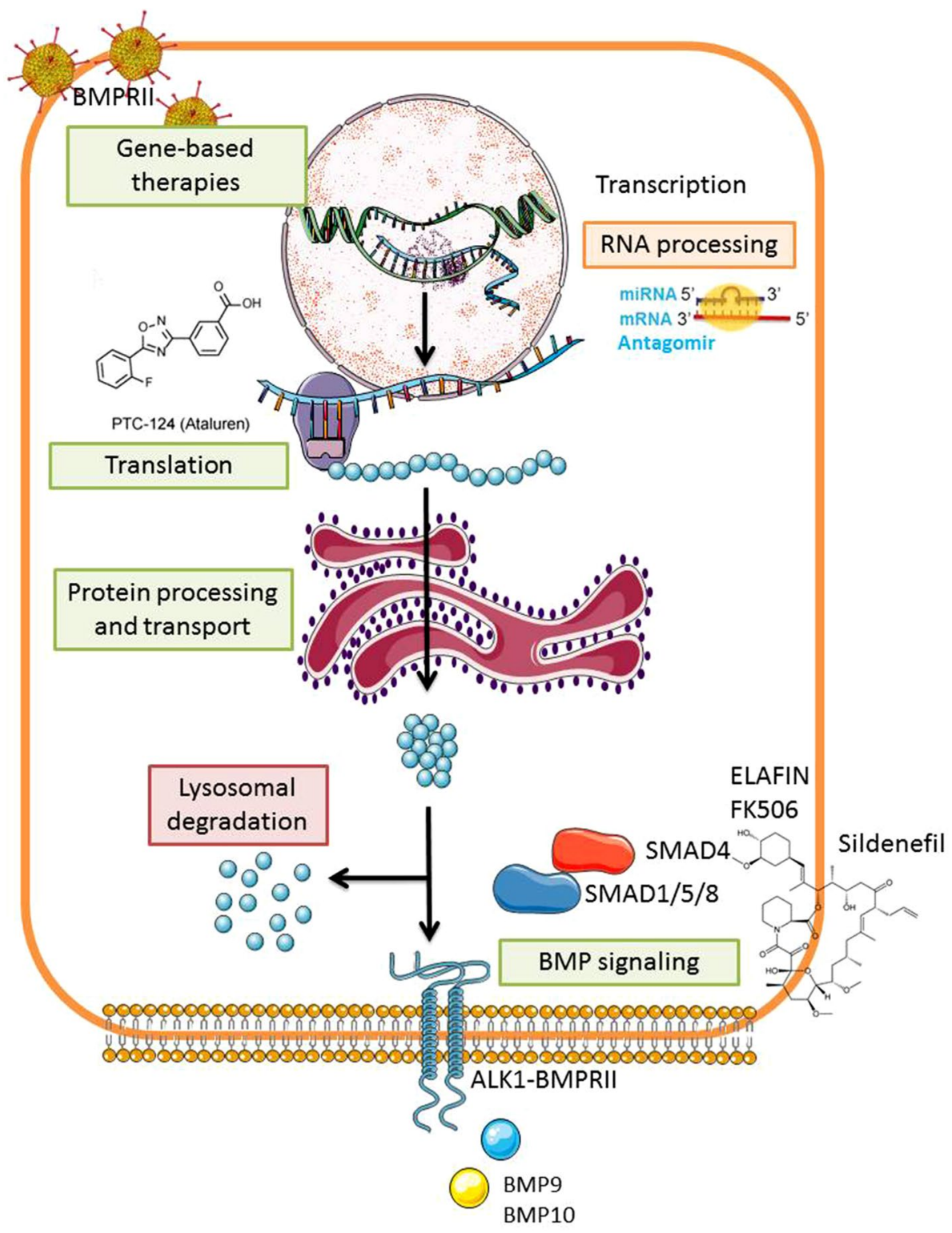

to the first-generation vectors. Moreover, they show neither long-term adverse effects in liver nor an immunological response [83, 84]. Taken together, exogenous BMPR2 delivery is a possible therapy for $\mathrm{PAH}$, but further improvements in vector technology are required to translate this approach to the clinic for the treatment of pulmonary vascular disease.

\section{Transcriptional regulation}

\section{miRNA targeting BMPRII}

In recent years, there has been an increasing interest in the role of epigenetics in the development of PAH [85, 86]. Epigenetics refers to heritable changes in gene expression that do not involve alterations in the DNA sequence.
miRNAs are small non-coding RNAs that negatively, posttranscriptionally regulate the expression of target genes by interfering with both the stability of the target transcript as well as its translation. miRNAs have emerged as essential players in the development (and diseases) of the cardiovascular system. They also play an important role in vascular remodeling $[87,88]$. miRNAs are expressed in the vasculature and are essential for the regulation of vessel function. Many miRNAs control proliferation, differentiation, and apoptosis of ECs and SMCs by targeting components of the TGF- $\beta$ /BMP signaling pathways. Several miRNAs, such as miR-145, miR-21 and the miR17/92 cluster, have been associated with the disrupted BMPRII pathway in $\mathrm{PAH}$ and can explain the incomplete penetrance of BMPR2 mutations [89-91]). Figure 4 and Table 1 provides an overview of currently described miRNAs that target BMPR2 
Fig. 4 miRNAs targeting BMPRII in the vascular wall.

The illustration shows hypoxia and BMPRII mutations as regulators of miRNAs expression in endothelial or smooth muscle cells. These miRNAs negatively regulate BMPRII expression resulting in increased cell proliferation and impaired apoptosis. Green arrows indicate activation, red arrows represent inhibition, and black arrows correspond to unknown regulation. $E C$ endothelial cells, $I L$ interleukin, $m i R$ micro RNA, mut mutant, SMC smooth muscle cell, STAT signal transducer, and activator of transcription

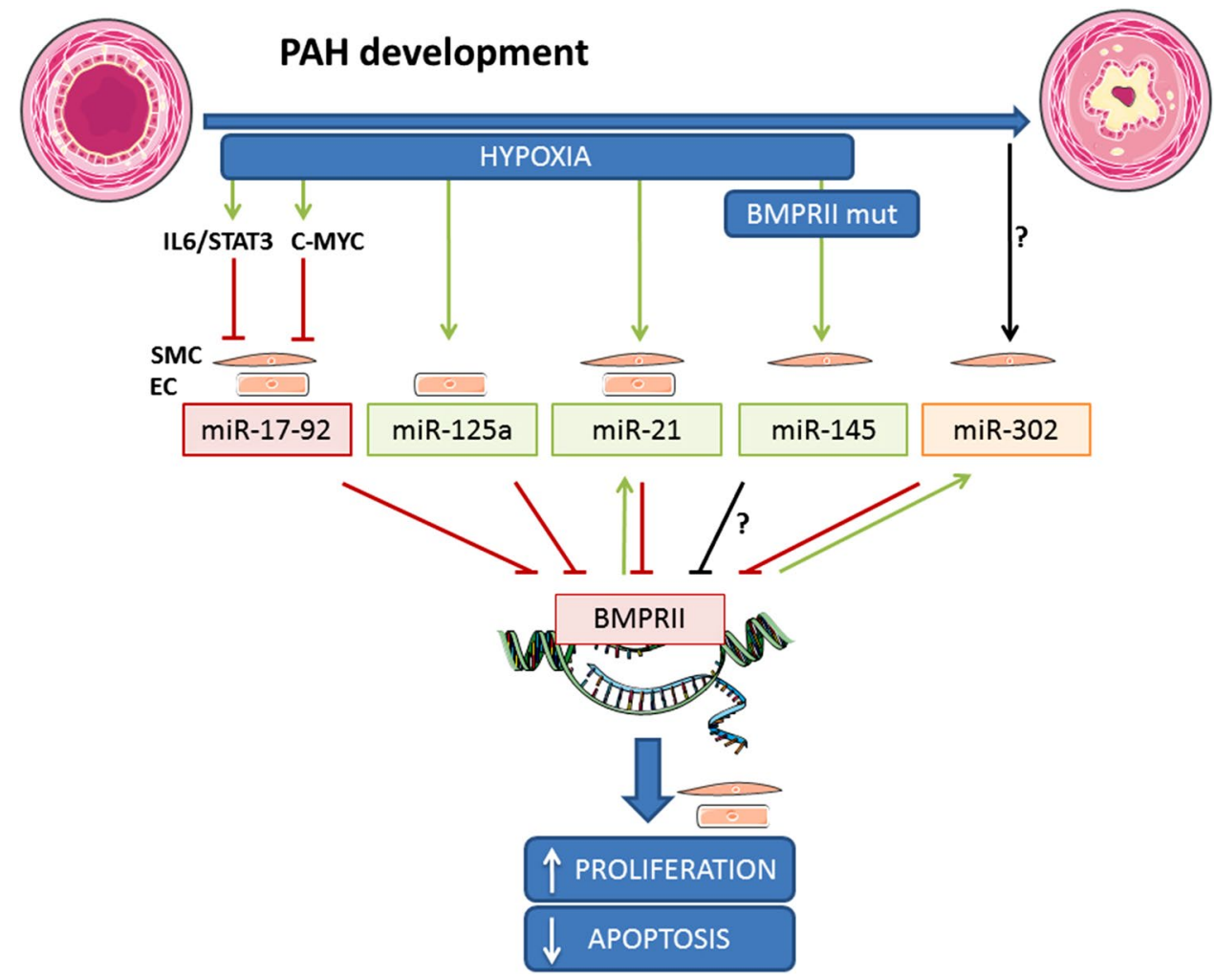

expression in vascular cells. In addition, Table 1 shows a list of other miRNAs that are predicted to target BMPR2 in silico.

Currently, there are different technologies to inhibit aberrantly overexpressed miRNAs including the use of antisense oligonucleotides, masking, sponges, erasers, or decoys [92, 93]. In addition, administration of miRNA mimics can enhance the expression of downregulated miRNAs [94]. These strategies are still under development and more research is needed to establish how modulation of miRNA function could offer therapeutic benefits in a clinical setting while avoiding off-target effects, especially in the liver, where systemically administrated miRNAs or modulating compounds preferentially accumulate [95].

The delivery routes mostly used to target lung disease are local intranasal and intra-tracheal administration. These naked miRNAs are directly delivered into the lung with minimal systemic side effects [96]. Nevertheless, this method remains ineffective and challenging due to the complexity of the lung [97]. Recent advances in delivery strategies, such as the use of liposomes, nanoparticles, or virus, combined with improvements in chemically modifying miRNAs, represent promising strategies to improve lung miRNA delivery [98]. More than 20 miRNAs are currently in clinical trials, several in Phase III stage, highlighting the potential of miRNA therapeutics to restore BMPRII in PAH [99]. To date, the potential for miRNAs as a therapeutic tool is relatively limited. Further studies focusing on the specificity, safety, efficiency, and stable systemic delivery of miRNAs into target cells or tissues will improve the process of translating these findings to the clinic.

\section{Translational regulation}

\section{Read-through premature STOP codons}

Most BMPR2 mutations $(\sim 70 \%)$ are non-sense mutations (frame-shift deletions and insertions) generated by the insertion of a premature termination codon (PTC) resulting in truncated reading frames which produce nonfunctional proteins [7]. To prevent formation of truncated proteins, mutated transcripts are directly degraded through non-sense mediated decay (NMD) resulting in insufficient amounts of the functional protein, which is produced only by the wild-type allele (haplo-insufficiency) [100, 101]. NMD usually does not completely reduce the levels of mutated transcripts and as a result truncated proteins persist, and may exert a DN effect [102].

An approach aimed to correct these types of mutations consists on the induction of PTC read-through. Readthrough of truncated mutations by aminoglycoside antibiotics, such as Gentamicin, has been extensively studied and has reached the clinical trial stage for genetic disorders such as cystic fibrosis [103] and Duchenne muscular dystrophy [104-110]. Aminoglycoside antibiotics bind to the decoding site of ribosomal RNA and eliminates the PTC 
Table 1 miRNA targeting BMPRII expression

\begin{tabular}{|c|c|c|c|c|c|}
\hline MicroRNA & Cell type & Function & Model & Expression & References \\
\hline \multirow[t]{2}{*}{ miR-17/92 } & $\mathrm{EC}$ & $\begin{array}{l}\text { Interleukin-6 modulates the expres- } \\
\text { sion of the BMPRII through a novel } \\
\text { STAT3-microRNA Cluster } 17 / 92 \\
\text { pathway }\end{array}$ & PAEC & $\exists$ & Brock et al. [13] \\
\hline & SMC & $\begin{array}{l}\text { Inhibition of miR-17 enhances } \\
\text { BMPRII expression and improves } \\
\text { heart and lung function in experi- } \\
\text { mental PH }\end{array}$ & $\begin{array}{l}\text { PASMC Hypoxia-induced PH mice } \\
\text { MCT-induced PH rats }\end{array}$ & $?$ & Pullamsetti et al. [164] \\
\hline miR-20A & SMC & $\begin{array}{l}\text { Treatment with antagomiR-20a } \\
\text { restores functional levels of BMPRII } \\
\text { in pulmonary arteries and prevents } \\
\text { the development of vascular remod- } \\
\text { eling }\end{array}$ & PASMC Hypoxia-induced PH mice & $?$ & Brock et al. [165] \\
\hline \multirow[t]{2}{*}{$\operatorname{miR}-21$} & $\mathrm{EC}$ & $\begin{array}{l}\text { Hypoxia and BMPRII signaling } \\
\text { independently upregulate miR-21. In } \\
\text { a reciprocal feedback loop, miR-21 } \\
\text { downregulates BMP receptor type II } \\
\text { expression }\end{array}$ & $\begin{array}{l}\text { PAEC Several rodent models of PH } \\
\text { miR-21-null mice }\end{array}$ & \# & Parikh et al. [166] \\
\hline & SMC & $\begin{array}{l}\text { BMPRII was downregulated in } \\
\text { PASMCs overexpressing miR-21 }\end{array}$ & PASMC Hypoxia-induced PH mice & \# & Yang et al. [167] \\
\hline miR-125 & $\mathrm{EC}$ & $\begin{array}{l}\text { Inhibition of miR-125a resulted in } \\
\text { upregulated BMPRII expression } \\
\text { accompanied by increased prolifera- } \\
\text { tion of EC }\end{array}$ & $\begin{array}{l}\text { PAEC Hypoxia-induced PH mice } \\
\text { Plasma PAH patients }\end{array}$ & \# & Huber et al. [168] \\
\hline miR-143/145 & $\mathrm{SMC}$ & $\begin{array}{l}\text { miR-145 expression is increased in } \\
\text { primary PASMCs cultured from } \\
\text { patients with BMPRII mutations and } \\
\text { in the lungs of BMPRII-deficient } \\
\text { mice }\end{array}$ & $\begin{array}{l}\text { PASMC Hypoxia-induced PH mice } \\
\text { BMPRII R899X knock-In Mice } \\
\text { miR-145 knock-Out Mice Lugn tis- } \\
\text { sue PAH patients }\end{array}$ & \# & Caruso et al. 2012 [169] \\
\hline miR-302 & SMC & $\begin{array}{l}\text { Inhibition of miR-302 by BMP4 } \\
\text { increases BMPRII expression } \\
\text { and facilitates the BMP signaling } \\
\text { pathway }\end{array}$ & PASMC & $?$ & Kang et al. 2012 [170] \\
\hline $\operatorname{miR}-181 \mathrm{c}$ & cardiac & $\begin{array}{l}\text { Increased miR-181c expression } \\
\text { in human cardiac samples from } \\
\text { individuals with ventricular septal } \\
\text { defects (VSD) was correlated with } \\
\text { downregulated BMPRII levels }\end{array}$ & Human VSD cardiac samples & \# & Li et al. [171] \\
\hline
\end{tabular}

by incorporating an amino acid to generate full-length proteins [111]. Importantly, this read-through function of aminoglycosides does not affect normal translation because of the presence of upstream and downstream regulatory sequences around a normal termination codon that ensure optimal efficiency of termination [112]. Gentamicin treatment has been tested in lymphocytes derived from two PAH patients with PTC mutations [113, 114]. The results demonstrated increased amounts of full-length BMPRII protein, a reduction in the mutated BMPRII product and enhanced BMPRII downstream signaling. Although aminoglycosides are commonly used in the clinic to treat infections and are safe when administered directly to the lung by inhalation, several side effects of long-term treatments and/ or high concentrations of the drug have been shown.
Recently, a high-throughput screening for compounds that suppress non-sense mutations identified a new small molecule named Ataluren (PTC124) which mediates read-through of premature stop codons without acute side effects [115]. Aldred et al. have demonstrated that after Ataluren treatment, BMPRII protein levels were normalized and BMP-dependent phosphorylation of the downstream target R-SMADs was increased in PAECs and PASMCs from PAH patients. In addition, the hyperproliferative phenotype of these cells was reversed even in the presence of significant non-sense mediated mRNA decay. Although, further studies, including animal models, are required to explore the relevance of Ataluren in vivo in a PAH context, the compound has emerged as a promising therapeutic strategy for a subset of PAH patients. 


\section{Protein processing regulation}

\section{Rescue of BMPRII trafficking}

$30 \%$ of $B M P R 2$ mutations are missense mutations leading to single amino acid substitutions in a conserved domain affecting the overall function of the protein [7]. Mutations resulting in the substitution of cysteine residues in the ligand binding and kinase domains disrupt protein folding and trafficking of BMPRII to the cell surface leading to retention of the mutant receptor in the endoplasmic reticulum (ER) $[113,116]$. A potentially promising therapeutic strategy to increase the expression of BMPRII at the plasma membrane is to enhance the activity of chaperones which facilitate protein folding and trafficking. This can be done by means of chemical chaperones such as sodium phenylbutyrate (4-PBA), probenecid, and tauroursodeoxycholic acid (TUDCA). These have been shown to improve protein trafficking via several distinct mechanisms [117-126]. Different groups have demonstrated that treatment with chemical chaperones can partially restore cell surface expression of BMPRII in ECs. As a result, BMP-induced SMAD 1/5/8 phosphorylation and the expression of the target gene ID1 is restored [127-129]. These agents are showing promise in clinical trials for other diseases caused by misfolded proteins, such as cystic fibrosis. Since the currently used chemical chaperones are federal drug administration (FDA) approved drugs, there is an immediate translational potential to treat PAH patients [118, 130-133]. However, further in vivo studies are required to test the viability of this approach.

Even though chemical chaperones have the potential to rescue the BMPRII mutants which are retained in the ER, it remains to be investigated whether the amount of BMPRII reaching the plasma membrane is enough to induce a clinically relevant effect. Also, BMPRII with a protein-folding defect expressed at the cell surface may have a dominantnegative activity and adverse effects on BMP signaling [127]. Moreover, patients harboring missense mutations that affect the activity of the receptor (kinase domain) may not benefit from this therapeutic strategy. Further research, taking this mutation variability into account, is required to determine which patients might benefit from this approach.

\section{Inhibition of lysosomal degradation}

The deciphering of mechanisms which regulate cell surface expression levels of BMPRII are of potential clinical importance, particularly those mechanisms that prevent its rapid turnover and thereby restore downstream BMPRII signaling and function. In this context, several studies focused on the potential of targeting the degradation of BMPRII by preventing lysosomal degradation
[134]. Durrington et al. have demonstrated that after Kaposi sarcoma-associated herpesvirus infection, BMPRII is ubiquitinated by K5 (membrane-associated RING E3 viral ubiquitin protein ligase) leading to lysosomal degradation in primary cultured pulmonary vascular cells [134]. In addition, cells treated with the lysosomal inhibitor concanamycin A exhibit increase levels of BMPRII. Furthermore, through siRNA screening of the NEDD4-like family E3 ubiquitin protein ligases, it was found that knockdown of ITCH expression resulted in increased BMPRII protein levels [134]. Whether ITCH ubiquitinates BMPRII, leading to lysosomal degradation, has yet to be investigated. Satow et al. have demonstrated that BMPRII is degraded via the proteosomal pathway in HEK 293T cells, when it is associated with Dullard phosphatase [135]. This might suggest that more than one mechanism accounts for BMPRII proteasomemediated degradation. It is noteworthy that Satow et al. used a BMPRII overexpression system, whereas Durrington et al. studied the degradation of endogenous BMPRII [134]. Different membrane trafficking pathways such as endocytosis, phagocytosis, micropinocytosis, and autophagy, use lysosomes for the digestion of diverse macromolecules [136]. Caveolae-mediated endocytosis affects multiple cellular signaling pathways by the redistribution of transmembrane receptors and receptor-ligand complexes [137-139]. BMPRII localization has been found to be regulated by CAV1 in vascular SMC [137]. Recently, ELAFIN (endogenous serine protease inhibitor) treatment has been shown to prevent and reverse PAH in the SU-hypoxia rat model. This occurs via elastase inhibition and by promoting the interaction of BMPRII with CAV1. Interestingly, when ELAFIN was combined with BMP9, there was enhanced co-localization of CAV1 and BMPRII on PAEC surfaces, which led at an increase in BMP9-dependent SMAD1/5 phosphorylation and induction of ID1 [137]. Furthermore, transgenic mice overexpressing human ELAVIN in the cardiovascular system (by placing ELAVIN expression under the control of the pre-proendothelin-1 promoter), exhibited reduced SMC proliferation and medial/intimal thickening after carotid artery wire injury [140] and were protected from hypoxic pulmonary hypertension [141]. In agreement with this, peptidyl trifluoromethylketone serine elastase inhibitors such as M249314 or ZD0892, have been used to prevent and reverse PAH in the MCT rat model [142]. However, the clinical use of these compounds was not pursued due to hepatotoxicity. ELAFIN has been shown to inhibit myocardial ischaemia-reperfusion injury induced during coronary artery bypass graft surgery [143]. Even though ELAFIN infusion was safe and resulted in $>50 \%$ inhibition of elastase activity in the first $24 \mathrm{~h}$, myocardial injury was not reduced after $48 \mathrm{~h}$. Based on the biology 
of ischemia-reperfusion injury and $\mathrm{PAH}$, we believe it is worth testing whether ELAFIN together with BMP9 could reverses PAH in patients.

Interestingly, autophagy has also been found to be involved in PAH. Autophagy (literally, "self-eating" in Greek) is a highly regulated catabolic process that involves sequestration and lysosomal degradation of cytosolic components such as dysfunctional organelles, misfolded proteins, lipid droplets, and invading pathogens [144]. Autophagy can be considered to be a general housekeeping mechanism maintaining the integrity of intracellular organelles and proteins. It is also triggered during development, differentiation, infection, and stress conditions. Thus, autophagy can be activated in the presence of damaged organelles, protein aggregates, intracellular pathogens, hypoxia, amino acid starvation, reactive oxygen species, and DNA damage [145]. Long et al. have shown that in rats suffering from PAH induced by MCT treatment, there is increased autophagy together with a decrease of BMPRII protein expression [146]. Moreover, inhibition of autophagic degradation by the lysosomal inhibitors chloroquine and hydroxychloroquine [147] prevents the development of PAH as well as its progression. The authors demonstrated that chloroquine and ATG5 (an autophagy protein involved in the elongation and closure of the autophagosomal membrane) knockdown inhibited proliferation and increased apoptosis of PASMCs and these effects correlated with increased levels of BMPRII via lysosomal inhibition. Although autophagy seems to be involved in the degradation of BMPRII, the exact mechanism by which this takes place has yet to be elucidated. Chloroquine and hydroxychloroquine have been widely utilized in malaria prophylaxis [148]. They have also been used to treat rheumatoid arthritis and lupus erythematosus (as anti-inflammatory agents) [148]. Since inflammation is thought to be a crucial second hit in PAH [149], these drugs might be effective at inhibiting PAH progression by impairing the degradation of BMPRII as well as inhibiting the inflammatory response. However, it is important to keep in mind that since lysosomal degradation is a ubiquitous cellular mechanism for regulating protein processing, this approach can lead to widespread and non-specific off-target effects independent of BMPRII signaling. Therefore, an improved understanding of the molecular mechanisms underlying BMPRII turnover is required for the development of more directed interventions.

\section{BMPRII signaling regulation}

\section{Delivery of exogenous BMP ligand}

As mentioned previously, BMP signaling in the vascular endothelium is mainly activated by BMP2, 4, 6, 9, and 10
[32]. In particular, BMP9 and BMP10 appear to play an important role in the vasculature due to their presence in the circulation and based on the fact that they are known to signal through receptors expressed on the endothelium, such as ALK1 and BMPRII or ACVRIIB. Therefore, the stimulation of BMP signaling with exogenous recombinant ligand is an interesting approach for PAH treatment $[11,150]$. Long et al. have shown that BMP9 prevents apoptosis and enhances the integrity of ECs in PAECs and blood outgrowth ECs from PAH patients. Furthermore, therapeutic BMP9 delivery prevents and reverses PAH in several mouse models [70]. BMP10 is the least studied BMP ligand; however, it may present a better treatment than BMP9 since it binds to ALK1 and BMPRII with higher affinity and because of its lack of osteogenic activity in vitro [151]. Further studies have to be performed to evaluate the delivery strategies, efficiency, and potential side effects of BMP9 and BMP10 in vivo. Finally, the development of a small peptide mimetics of BMP9 or BMP10, with an increased affinity for the receptor, is a theoretical alternative for efficiently activating BMP signaling and thereby reversing PAH [150].

\section{Enhance downstream SMAD signaling}

An additional approach to reverse the effect of mutant BMPRII is use small molecules to enhance signaling of the wild-type functional proteins. Sildenafil is a phosphodiesterase type-5 (PDE5) inhibitor currently used in the clinic for PAH treatment [152-154]. Its mode of action is to block the degradation of cyclic guanosine monophosphate (cGMP) resulting in corrective vasodilatory and anti-proliferative effects in the arterial wall [155]. Furthermore, it has been described that protein kinase $\mathrm{G}$ (PKG) activated by cGMP, is a modulator of BMP signaling [156] and that PASMCs expressing a BMPRII mutant, showed an increase in BMP signaling after Sildenadil treatment via a cGMP/ PKG-dependent mechanism. In addition, in vivo studies confirmed that Sildenafil treatment enhanced BMP signaling and partially reversed PAH development in the MCT rat model [157, 158]. Although Sildenafil therapy during 12 weeks improves multiple clinical symptoms in PAH patients, it appears to have no effect on reducing either mortality or serious adverse events [159]. Furthermore, the long-term efficiency and safety of Sildenafil therapy in PAH requires further studies based on large and well-designed clinical trials [159].

Another promising strategy is to identify compounds in drug libraries that activate BMP/SMAD signaling. FK506 (Tacrolimus) was identified as the best BMP coactivator among 3756 FDA-approved drugs and bioactive compounds (using a high-throughput BMP/SMAD-driven transcriptional reporter assay) [160]. FK506 promotes BMP 
signaling and endothelial-specific gene regulation of genes such as APELIN. This occurs even in the absence of exogenous ligand via a dual mechanism of action: acting as an inhibitor of phosphatase CALCINEURIN and binding FKbinding protein-12 (FKBP12), a repressor of BMP signaling. FK506 promotes the release of FKBP12 from the type I receptor which leads to activation of SMAD1/5 downstream of BMP as well as MAPK signaling and ID1 gene regulation [161]. Furthermore, FK506 treatment increases ALK1 and ENDOGLIN expression in ECs [162]. Recently, a randomized, double-blind, placebo-controlled phase IIa trial was performed to investigate the efficacy of FK506 treatment in three patients with end-stage PAH. The results suggest a potential clinical benefit of low-dose FK506 (the evidence being that patients demonstrated cardiac function stabilization and required less intensive hospital care for RV failure despite the severity of the illness). It was also found that changes in serologic biomarkers indicated that BMPRII had been successfully targeted [163]. However, these results are based on a limited group of patients and the efficacy of this therapy must be validated in appropriate, well-designed clinical trials. FK506 (also known as Tacrolimus) is an immunosuppressive drug with a known pharmacokinetic and toxicity profile. It is widely used in solid organ transplantations to lower the risk of organ rejection [164]. High doses of FK506 caused systemic hypertension and transplant vasculopathy in animal models [165]. Also, organ transplant patients treated with FK506, have an increased risk of renal injury, which might occur due to the inhibition of calcineurin expression in the kidney [166-168]. In contrast, low doses of FK506 did not induce systemic hypertension in animal models, even after 3 weeks of treatment. FK506 has shown significant clinical benefits, nonetheless long-term use of this agent for treating PAH still needs to be rigorously monitored for toxicity effects.

\section{Conclusions and perspectives}

Exogenous BMPRII delivery to ECs has been shown to be an effective means to restore BMPRII expression and function $[77,78]$. An interesting approach, which is yielding promising results in mice, is to deliver BMPRII specifically to ECs using BMPRII adenoviral vectors carrying a bi-specific conjugate antibody that targets the virus to ACE, a membrane-bound protease highly expressed on pulmonary endothelial cells [77, 78]. One of the drawbacks of this strategy is the use of two components namely, adenovirus and antibody. Additional restrictions related to the use of viral transduction such as safety, specificity, and delivery of sufficient protein to revert the phenotype must also be taken into consideration. The utilization of
CRISPR/Cas9 may overcome some of these limitations, for instance by minimizing the risk that the foreign gene will be integrated in the wrong place in the genome. Furthermore, it will place the gene under the control of its natural promoter. However, the delivery of CRISPR/Cas9 into the patient is still challenging and the Cas9 enzyme could cleave at unwanted locations. Similarly, the use of miRNAs targeting BMPRII has to be evaluated for off-target effects and an effective delivery system has to be found in order to consider this approach as a promising treatment. A solution for both plasmid DNA and miRNA delivery might be the use of liposomes [169] or iTOP (induced transduction by osmocytosis and propanebetaine), which is an active uptake mechanism in which $\mathrm{NaCl}$-mediated hyperosmolarity together with propanebetaine triggers the uptake of macromolecules [170]. Another therapeutic strategy is the use of FDA-approved drugs that have been found to be beneficial in PAH mice models or similar diseases. Ataluren, for example, allows the cellular machinery to read-through premature stop codons [115]. Although most of the BMPR2 mutations ( 70\%) are non-sense mutations, not all patients will benefit from this approach. Nevertheless, further in vivo studies are worth pursuing in the context of PAH. Likewise, clinical trials using chloroquine have to be performed to test its effectiveness in PAH patients. The use of chloroquine has to be carefully evaluated because blocking lysosomal degradation might trigger non-specific off-target effects when used as a long-term treatment. An alternative drug showing significant clinical benefits for PAH is FK506/Tacrolimus. However, it still needs to be monitored for side effects since it is an immunosuppressive drug (currently utilized after allogeneic organ transplant). Moreover, the effectiveness of FK506 at low doses has to be rigorously tested.

It is important to highlight that although several drugs showed beneficial outcomes in animal models, most of the drugs have failed in the clinic. In light of this, we should focus on a more personalized approach which takes into account the co-existence of modifier genes, infections, toxic exposure, inflammation, or alterations in estrogen metabolism. Combining treatments which target not only BMPRII signaling but also inflammation and hypoxia should improve outcomes. Lastly, the use of human ex vivo models such as lung or vessel on a chip [171] could be beneficial for drug discovery and efficacy testing in the context of PAH. We anticipate that such models may improve the relevance of pre-clinical results by using patient derived cells, especially since animal models of PAH are frequently difficult to translate into clinical practice.

Taken together, previously discussed data suggest that modulation of BMPRII signaling in PAH is a promising alternative that could prevent and reverse pulmonary vascular remodeling. However, different therapeutic approaches 
aimed at to increasing the levels of BMPRII signaling are needed, and these approaches will depend on the particular genetic background of each patient. In addition, for more efficient treatments, targeting other genetic and environmental factors that contribute to the disease must be taken into consideration. In this regard, modulators of the inflammatory response and estrogen metabolism could be used to help restore BMPRII signaling.

\begin{abstract}
Acknowledgements We acknowledge the support from the Netherlands CardioVascular Research Initiative: the Dutch Heart Foundation, Dutch Federation of University Medical Centers, the Netherlands Organisation for Health Research and Development, and the Royal Netherlands Academy of Sciences.
\end{abstract}

Open Access This article is distributed under the terms of the Creative Commons Attribution 4.0 International License (http:// creativecommons.org/licenses/by/4.0/), which permits unrestricted use, distribution, and reproduction in any medium, provided you give appropriate credit to the original author(s) and the source, provide a link to the Creative Commons license, and indicate if changes were made.

\section{References}

1. Rosenkranz S (2015) Pulmonary hypertension 2015: current definitions, terminology, and novel treatment options. Clin Res Cardiol 104(3):197-207. doi:10.1007/s00392-014-0765-4

2. Guignabert C, Dorfmuller P (2013) Pathology and pathobiology of pulmonary hypertension. Semin Respir Crit Care Med 34(5):551-559. doi:10.1055/s-0033-1356496

3. Farber HW, Loscalzo J (2004) Pulmonary arterial hypertension. N Engl J Med 351(16):1655-1665. doi:10.1056/NEJMra035488

4. Thompson K, Rabinovitch M (1996) Exogenous leukocyte and endogenous elastases can mediate mitogenic activity in pulmonary artery smooth muscle cells by release of extracellularmatrix bound basic fibroblast growth factor. J Cell Physiol 166(3):495-505. doi:10.1002/(sici)1097-4652(199603)

5. Consortium IP, Lane KB, Machado RD, Pauciulo MW, Thomson JR, Phillips JA, Loyd JE, Nichols WC, Trembath RC (2000) Heterozygous germline mutations in BMPR2, encoding a TGFbeta receptor, cause familial primary pulmonary hypertension. Nat Genet 26(1):81-84. doi:10.1038/79226

6. Deng Z, Morse JH, Slager SL, Cuervo N, Moore KJ, Venetos G, Kalachikov S, Cayanis E, Fischer SG, Barst RJ, Hodge SE, Knowles JA (2000) Familial primary pulmonary hypertension (gene PPH1) is caused by mutations in the bone morphogenetic protein receptor-II gene. Am J Hum Genet 67(3):737-744. doi:10.1086/303059

7. Machado RD, Aldred MA, James V, Harrison RE, Patel B, Schwalbe EC, Gruenig E, Janssen B, Koehler R, Seeger W, Eickelberg O, Olschewski H, Elliott CG, Glissmeyer E, Carlquist J, Kim M, Torbicki A, Fijalkowska A, Szewczyk G, Parma J, Abramowicz MJ, Galie N, Morisaki H, Kyotani S, Nakanishi N, Morisaki T, Humbert M, Simonneau G, Sitbon O, Soubrier F, Coulet F, Morrell NW, Trembath RC (2006) Mutations of the TGF-beta type II receptor BMPR2 in pulmonary arterial hypertension. Hum Mutat 27(2):121-132. doi:10.1002/ humu. 20285

8. Thomson JR, Machado RD, Pauciulo MW, Morgan NV, Humbert M, Elliott GC, Ward K, Yacoub M, Mikhail G, Rogers P,
Newman J, Wheeler L, Higenbottam T, Gibbs JS, Egan J, Crozier A, Peacock A, Allcock R, Corris P, Loyd JE, Trembath RC, Nichols WC (2000) Sporadic primary pulmonary hypertension is associated with germline mutations of the gene encoding BMPR-II, a receptor member of the TGF-beta family. J Med Genet 37(10):741-745

9. Machado RD, Southgate L, Eichstaedt CA, Aldred MA, Austin ED, Best DH, Chung WK, Benjamin N, Elliott CG, Eyries M, Fischer C, Gräf S, Hinderhofer K, Humbert M, Keiles SB, Loyd JE, Morrell NW, Newman JH, Soubrier F, Trembath RC, Viales RR, Grünig E (2015) Pulmonary arterial hypertension: a current perspective on established and emerging molecular genetic defects. Hum Mutat 36(12):1113-1127. doi:10.1002/ humu. 22904

10. Cogan J, Austin E, Hedges L, Womack B, West J, Loyd J, Hamid R (2012) Role of BMPR2 alternative splicing in heritable pulmonary arterial hypertension penetrance. Circulation 126(15):1907-1916. doi:10.1161/ CIRCULATIONAHA.112.106245

11. Guignabert C, Bailly S, Humbert M (2017) Restoring BMPRII functions in pulmonary arterial hypertension: opportunities, challenges and limitations. Expert Opin Ther Targets 21(2):181-190. doi:10.1080/14728222.2017.1275567

12. Song Y, Coleman L, Shi J, Beppu H, Sato K, Walsh K, Loscalzo J, Zhang Y-Y (2008) Inflammation, endothelial injury, and persistent pulmonary hypertension in heterozygous BMPR2mutant mice. Am J Physiol Heart Circ Physiol 295(2):H677H690. doi:10.1152/ajpheart.91519.2007

13. Austin ED, Cogan JD, West JD, Hedges LK, Hamid R, Dawson EP, Wheeler LA, Parl FF, Loyd JE, Phillips JA (2009) Alterations in oestrogen metabolism: implications for higher penetrance of familial pulmonary arterial hypertension in females. Eur Respir J 34(5):1093-1099. doi:10.1183/09031936.00010409

14. Mair KM, Yang XD, Long L, White K, Wallace E, Ewart M-A, Docherty CK, Morrell NW, MacLean MR (2015) Sex affects bone morphogenetic protein type II receptor signaling in pulmonary artery smooth muscle cells. Am J Respir Crit Care Med 191(6):693-703. doi:10.1164/rccm.201410-1802OC

15. Brock M, Trenkmann M, Gay RE, Michel BA, Gay S, Fischler M, Ulrich S, Speich R, Huber LC (2009) Interleukin-6 modulates the expression of the bone morphogenic protein receptor type II through a novel STAT3-microRNA cluster 17/92 pathway. Circ Res 104(10):1184-1191. doi:10.1161/ circresaha.109.197491

16. Kim CW, Song H, Kumar S, Nam D, Kwon HS, Chang KH, Son DJ, Kang DW, Brodie SA, Weiss D, Vega JD, Alberts-Grill N, Griendling K, Taylor WR, Jo H (2013) Anti-inflammatory and antiatherogenic role of BMP receptor II in endothelial cells. Arterioscler Thromb Vasc Biol 33(6):1350-1359. doi:10.1161/ ATVBAHA.112.300287

17. Soon E, Crosby A, Southwood M, Yang P, Tajsic T, Toshner M, Appleby S, Shanahan CM, Bloch KD, Pepke-Zaba J, Upton P, Morrell NW (2015) Bone morphogenetic protein receptor type II deficiency and increased inflammatory cytokine production. A gateway to pulmonary arterial hypertension. Am J Respir Crit Care Med 192(7):859-872. doi:10.1164/rccm.201408-1509OC

18. Burton VJ, Ciuclan LI, Holmes AM, Rodman DM, Walker C, Budd DC (2011) Bone morphogenetic protein receptor II regulates pulmonary artery endothelial cell barrier function. Blood 117(1):333-341. doi:10.1182/blood-2010-05-285973

19. Frumkin LR (2012) The pharmacological treatment of pulmonary arterial hypertension. Pharmacol Rev 64(3):583-620. doi:10.1124/pr.111.005587

20. Perrin S, Chaumais M-C, O'Connell C, Amar D, Savale L, Jaïs X, Montani D, Humbert M, Simonneau G, Sitbon O 
(2015) New pharmacotherapy options for pulmonary arterial hypertension. Expert Opin Pharmacother 16(14):2113-2131. doi:10.1517/14656566.2015.1074177

21. Morrell NW, Archer SL, Defelice A, Evans S, Fiszman M, Martin T, Saulnier M, Rabinovitch M, Schermuly R, Stewart D, Truebel H, Walker G, Stenmark KR (2013) Anticipated classes of new medications and molecular targets for pulmonary arterial hypertension. Pulm Circ 3(1):226-244. doi:10.4103/2045-8932.109940

22. Stenmark KR, Rabinovitch M (2010) Emerging therapies for the treatment of pulmonary hypertension. Pediatr Crit Care Med 11(2):S85-S90. doi:10.1097/PCC.0b013e3181c76db3

23. Balliga RS, MacAllister RJ, Hobbs AJ (2011) New perspectives for the treatment of pulmonary hypertension. $\mathrm{Br} \mathrm{J}$ Pharmacol 163(1):125-140. doi:10.1111/j.1476-5381.2010.01164.x

24. Liu Y, Ren W, Warburton R, Toksoz D, Fanburg BL (2009) Serotonin induces Rho/ROCK-dependent activation of Smads $1 / 5 / 8$ in pulmonary artery smooth muscle cells. FASEB $\mathbf{J}$ 23(7):2299-2306. doi:10.1096/fj.08-127910

25. Akhurst RJ, Padgett RW (2015) Matters of context guide future research in TGF $\beta$ superfamily signaling. Sci Signal 8(399):re10. doi:10.1126/scisignal.aad0416

26. Sánchez-Duffhues G, Hiepen C, Knaus P, Ten Dijke P (2015) Bone morphogenetic protein signaling in bone homeostasis. Bone 80:43-59. doi:10.1016/j.bone.2015.05.025

27. Morrell NW, Bloch DB,Ten Dijke P, Goumans M-JTH, Hata A, Smith J, Yu PB, Bloch KD (2016) Targeting BMP signalling in cardiovascular disease and anaemia. Nat Rev Cardiol 13(2):106-120. doi:10.1038/nrcardio.2015.156

28. Kawabata M, Imamura T, Miyazono K (1998) Signal transduction by bone morphogenetic proteins. Cytokine Growth Factor Rev 9(1):49-61

29. Miyazono K, Kamiya Y, Morikawa M (2010) Bone morphogenetic protein receptors and signal transduction. J Biochem 147(1):35-51. doi:10.1093/jb/mvp148

30. Heldin CH, Miyazono K, Ten Dijke P (1997) TGF-beta signalling from cell membrane to nucleus through SMAD proteins. Nature 390(6659):465-471. doi:10.1038/37284

31. Derynck R, Zhang YE (2003) Smad-dependent and Smadindependent pathways in TGF-beta family signalling. Nature 425(6958):577-584. doi:10.1038/nature02006

32. David L, Feige J-J, Bailly S (2009) Emerging role of bone morphogenetic proteins in angiogenesis. Cytokine Growth Factor Rev 20(3):203-212. doi:10.1016/j.cytogfr.2009.05.001

33. Feng X-H, Derynck R (2005) Specificity and versatility in tgf-beta signaling through Smads. Annu Rev Cell Dev Biol 21:659-693. doi:10.1146/annurev.cellbio.21.022404.142018

34. Shi Y, Massagué J (2003) Mechanisms of TGF-beta signaling from cell membrane to the nucleus. Cell 113(6):685-700

35. Zhang YE (2009) Non-Smad pathways in TGF-beta signaling. Cell Res 19(1):128-139. doi:10.1038/cr.2008.328

36. Moustakas A, Heldin C-H (2005) Non-Smad TGF-beta signals. J Cell Sci 118(Pt 16):3573-3584. doi:10.1242/jcs.02554

37. Mu Y, Gudey SK, Landström M (2012) Non-Smad signaling pathways. Cell Tissue Res 347(1):11-20. doi:10.1007/ s00441-011-1201-y

38. Massagué J, Wotton D (2000) Transcriptional control by the TGF-beta/Smad signaling system. EMBO J 19(8):1745-1754. doi:10.1093/emboj/19.8.1745

39. Mulder KM (2000) Role of ras and mapks in TGFbeta signaling. Cytokine Growth Factor Rev 11(1-2):23-35

40. Canalis E, Economides AN, Gazzerro E (2003) Bone morphogenetic proteins, their antagonists, and the skeleton. Endocr Rev 24(2):218-235. doi:10.1210/er.2002-0023
41. Sánchez-Duffhues G, Hiepen C, Knaus $P$, Ten Dijke $P$ (2016) Emerging regulators of BMP bioavailability. Bone. doi:10.1016/j.bone.2016.01.022

42. Cai J, Pardali E, Sánchez-Duffhues G, Ten Dijke P (2012) BMP signaling in vascular diseases. FEBS Lett 586(14):1993-2002. doi:10.1016/j.febslet.2012.04.030

43. Gao X, Cao Y, Staloch DA, Gonzales MA, Aronson JF, Chao C, Hellmich MR, Ko TC (2014) Bone morphogenetic protein signaling protects against cerulein-induced pancreatic fibrosis. PLoS ONE 9(2):e89114. doi:10.1371/journal.pone.0089114

44. Chen NY, S DC, Luo F, Weng T, Le TT, A MH, Philip K, Molina JG, Garcia-Morales LJ, Cao Y, Ko TC, Amione-Guerra J, Al-Jabbari O, Bunge RR, Youker K, Bruckner BA, Hamid R, Davies J, Sinha N, Karmouty-Quintana H (2016) Macrophage bone morphogenic protein receptor 2 depletion in idiopathic pulmonary fibrosis and Group III pulmonary hypertension. Am J Physiol Lung Cell Mol Physiol 311(2):L238-L254. doi:10.1152/ajplung.00142.2016

45. De Vinuesa AG, Abdelilah-Seyfried S, Knaus P, Zwijsen A, Bailly S (2016) BMP signaling in vascular biology and dysfunction. Cytokine Growth Factor Rev 27:65-79. doi:10.1016/j. cytogfr.2015.12.005

46. Stenmark KR, Davie N, Frid M, Gerasimovskaya E, Das M (2006) Role of the adventitia in pulmonary vascular remodeling. Physiology (Bethesda) 21:134-145. doi:10.1152/ physiol.00053.2005

47. Humbert M, Morrell NW, Archer SL, Stenmark KR, MacLean MR, Lang IM, Christman BW, Weir EK, Eickelberg O, Voelkel NF, Rabinovitch M (2004) Cellular and molecular pathobiology of pulmonary arterial hypertension. J Am Coll Cardiol 43(12):13 S-24 S. doi:10.1016/j.jacc.2004.02.029

48. Lilly B (2014) We have contact: endothelial cell-smooth muscle cell interactions. Physiology (Bethesda) 29(4):234-241. doi:10.1152/physiol.00047.2013

49. Christman BW, McPherson CD, Newman JH, King GA, Bernard GR, Groves BM, Loyd JE (1992) An imbalance between the excretion of thromboxane and prostacyclin metabolites in pulmonary hypertension. N Engl J Med 327:70-75. doi:10.1056/NEJM199207093270202

50. David L, Mallet C, Mazerbourg S, Feige J-J, Bailly S (2007) Identification of BMP9 and BMP10 as functional activators of the orphan activin receptor-like kinase 1 (ALK1) in endothelial cells. Blood 109(5):1953-1961. doi:10.1182/ blood-2006-07-034124

51. Scharpfenecker M, van Dinther M, Liu Z, van Bezooijen RL, Zhao Q, Pukac L, Löwik CWGM, Ten Dijke P (2007) BMP-9 signals via ALK1 and inhibits bFGF-induced endothelial cell proliferation and VEGF-stimulated angiogenesis. J Cell Sci 120(Pt 6):964-972. doi:10.1242/jcs.002949

52. Upton PD, Long L, Trembath RC, Morrell NW (2008) Functional characterization of bone morphogenetic protein binding sites and Smad1/5 activation in human vascular cells. Mol Pharmacol 73(2):539-552. doi:10.1124/mol.107.041673

53. Shintani M, Yagi H, Nakayama T, Saji T, Matsuoka R (2009) A new nonsense mutation of SMAD8 associated with pulmonary arterial hypertension. J Med Genet 46:331-337. doi:10.1136/ jmg.2008.062703

54. Nasim MT, Ogo T, Ahmed M, Randall R, Chowdhury HM, Snape KM, Bradshaw TY, Southgate L, Lee GJ, Jackson I, Lord GM, Gibbs JS, Wilkins MR, Ohta-Ogo K, Nakamura K, Girerd B, Coulet F, Soubrier F, Humbert M, Morrell NW, Trembath RC, Machado RD (2011) Molecular genetic characterization of SMAD signaling molecules in pulmonary arterial hypertension. Hum Mutat 32(12):1385-1389. doi:10.1002/humu.21605

55. Wang G, Fan R, Ji R, Zou W, Penny DJ, Varghese NP, Fan Y (2016) Novel homozygous BMP9 nonsense mutation causes 
pulmonary arterial hypertension: a case report. BMC Pulm Med 16:17. doi:10.1186/s12890-016-0183-7

56. Shintani M, Yagi H, Nakayama T, Saji T, Matsuoka R (2009) A new nonsense mutation of SMAD8 associated with pulmonary arterial hypertension. J Med Genet 46(5):331-337. doi:10.1136/jmg.2008.062703

57. Harrison RE, Berger R, Haworth SG, Tulloh R, Mache CJ, Morrell NW, Aldred MA, Trembath RC (2005) Transforming growth factor- $\beta$ receptor mutations and pulmonary arterial hypertension in childhood. Circulation 111(4):435-441. doi:10.1161/01.CIR.0000153798.78540.87

58. Girerd B, Montani D, Coulet F, Sztrymf B, Yaici A, Jais X, Tregouet D, Reis A, Drouin-Garraud V, Fraisse A, Sitbon O, O'Callaghan DS, Simonneau G, Soubrier F, Humbert M (2010) Clinical outcomes of pulmonary arterial hypertension in patients carrying an ACVRL1 (ALK1) mutation. Am J Respir Crit Care Med 181(8):851-861. doi:10.1164/ rccm.200908-12840C

59. Pousada G, Baloira A, Fontan D, Nunez M, Valverde D (2016) Mutational and clinical analysis of the ENG gene in patients with pulmonary arterial hypertension. BMC Genet 17(1):72. doi:10.1186/s12863-016-0384-3

60. Austin ED, Ma L, LeDuc C, Berman Rosenzweig E, Borczuk A, Phillips JA, Palomero T, Sumazin P, Kim HR, Talati MH, West J, Loyd JE, Chung WK (2012) Whole exome sequencing to identify a novel gene (caveolin-1) associated with human pulmonary arterial hypertension. Circ Cardiovasc Genet 5(3):336-343. doi:10.1161/circgenetics.111.961888

61. Ma L, Roman-Campos D, Austin ED, Eyries M, Sampson KS, Soubrier F, Germain M, Trégouët D-A, Borczuk A, Rosenzweig EB, Girerd B, Montani D, Humbert M, Loyd JE, Kass RS, Chung WK (2013) A novel channelopathy in pulmonary arterial hypertension. N Engl J Med 369(4):351-361. doi:10.1056/NEJMoa1211097

62. Ranchoux B, Antigny F, Rucker-Martin C, Hautefort A, Pechoux C, Bogaard HJ, Dorfmuller P, Remy S, Lecerf F, Plante S, Chat S, Fadel E, Houssaini A, Anegon I, Adnot S, Simonneau G, Humbert M, Cohen-Kaminsky S, Perros F (2015) Endothelial-to-mesenchymal transition in pulmonary hypertension. Circulation 131(11):1006-1018. doi:10.1161/ CIRCULATIONAHA.114.008750

63. Hopper RK, Moonen JR, Diebold I, Cao A, Rhodes CJ, Tojais NF, Hennigs JK, Gu M, Wang L, Rabinovitch M (2016) In pulmonary arterial hypertension, reduced BMPR2 promotes endothelial-to-mesenchymal transition via HMGA1 and its target slug. Circulation 133(18):1783-1794. doi:10.1161/ CIRCULATIONAHA.115.020617

64. Maron BA, Loscalzo J (2013) Pulmonary hypertension: pathophysiology and signaling pathways. Handb Exp Pharmacol 218:31-58. doi:10.1007/978-3-642-38664-0_2

65. Voelkel NF, Tuder RM (2000) Hypoxia-induced pulmonary vascular remodeling: a model for what human disease? J Clin Invest 106(6):733-738. doi:10.1172/JCI11144

66. Campian ME, Hardziyenka M, Michel MC, Tan HL (2006) How valid are animal models to evaluate treatments for pulmonary hypertension? Naunyn Schmiedebergs Arch Pharmacol 373(6):391-400. doi:10.1007/s00210-006-0087-9

67. Guihaire J, Bogaard HJ, Flecher E, Noly PE, Mercier O, Haddad F, Fadel E (2013) Experimental models of right heart failure: a window for translational research in pulmonary hypertension. Semin Respir Crit Care Med 34(5):689-699. doi:10.1055/s-0033-1355444

68. West J, Fagan K, Steudel W, Fouty B, Lane K, Harral J, Hoedt-Miller M, Tada Y, Ozimek J, Tuder R, Rodman DM (2004) Pulmonary hypertension in transgenic mice expressing a dominant-negative BMPRII gene in smooth muscle. Circ Res 94(8):1109-1114. doi:10.1161/01. res.0000126047.82846.20

69. Hong K-H, Lee YJ, Lee E, Park SO, Han C, Beppu H, Li E, Raizada MK, Bloch KD, Oh SP (2008) Genetic ablation of the BMPR2 gene in pulmonary endothelium is sufficient to predispose to pulmonary arterial hypertension. Circulation 118(7):722-730. doi:10.1161/circulationaha.107.736801

70. Long L, Ormiston ML, Yang X, Southwood M, Graf S, Machado RD, Mueller M, Kinzel B, Yung LM, Wilkinson JM, Moore SD, Drake KM, Aldred MA, Yu PB, Upton PD, Morrell NW (2015) Selective enhancement of endothelial BMPR-II with BMP9 reverses pulmonary arterial hypertension. Nat Med 21(7):777-785. doi:10.1038/nm.3877

71. Maarman G, Lecour S, Butrous G, Thienemann F, Sliwa K (2013) A comprehensive review: the evolution of animal models in pulmonary hypertension research; are we there yet?. Pulm Circ 3(4):739-756. doi:10.1086/674770

72. West J, Harral J, Lane K, Deng Y, Ickes B, Crona D, Albu S, Stewart D, Fagan K (2008) Mice expressing BMPR2R899X transgene in smooth muscle develop pulmonary vascular lesions. Am J Physiol Lung Cell Mol Physiol 295(5):L744L755. doi:10.1152/ajplung.90255.2008

73. de Jesus Perez VA, Alastalo T-P, Wu JC, Axelrod JD, Cooke JP, Amieva M, Rabinovitch M (2009) Bone morphogenetic protein 2 induces pulmonary angiogenesis via Wnt-beta-catenin and Wnt-RhoA-Rac1 pathways. J Cell Biol 184(1):83-99. doi:10.1083/jcb.200806049

74. Hansmann G, de Jesus Perez VA, Alastalo T-P, Alvira CM, Guignabert C, Bekker JM, Schellong S, Urashima T, Wang L, Morrell NW, Rabinovitch M (2008) An antiproliferative BMP-2/PPARgamma/apoE axis in human and murine SMCs and its role in pulmonary hypertension. J Clin Invest 118(5):1846-1857. doi:10.1172/jci32503

75. Sung YK, Yuan K, de Jesus Perez VA (2016) Novel approaches to pulmonary arterial hypertension drug discovery. Expert Opin Drug Discov 11(4):407-414. doi:10.1517/17460441.2016.1153 625

76. Madonna R, Cocco N (2016) Novel strategies in the treatment of pulmonary arterial hypertension. Curr Drug Targets 17(7):817-823

77. Reynolds AM, Xia W, Holmes MD, Hodge SJ, Danilov S, Curiel DT, Morrell NW, Reynolds PN (2007) Bone morphogenetic protein type 2 receptor gene therapy attenuates hypoxic pulmonary hypertension. Am J Physiol Lung Cell Mol Physiol 292(5):L1182-L1192. doi:10.1152/ajplung.00020.2006

78. Reynolds AM, Holmes MD, Danilov SM, Reynolds PN (2012) Targeted gene delivery of BMPR2 attenuates pulmonary hypertension. Eur Respir J 39(2):329-343. doi:10.1183/09031936.00187310

79. Harper RL, Reynolds AM, Bonder CS, Reynolds PN (2016) BMPR2 gene therapy for PAH acts via Smad and non-Smad signalling. Respirology 21(4):727-733. doi:10.1111/resp.12729

80. McMurtry MS, Moudgil R, Hashimoto K, Bonnet S, Michelakis ED, Archer SL (2007) Overexpression of human bone morphogenetic protein receptor 2 does not ameliorate monocrotaline pulmonary arterial hypertension. Am J Physiol Lung Cell Mol Physiol 292(4):L872-L878. doi:10.1152/ajplung.00309.2006

81. Doi K, Takeuchi Y (2015) Gene therapy using retrovirus vectors: vector development and biosafety at clinical trials. Uirusu 65(1):27-36. doi:10.2222/jsv.65.27

82. Reynolds PN (2011) Viruses in pharmaceutical research: pulmonary vascular disease. Mol Pharm 8(1):56-64. doi:10.1021/ mp1003477

83. Brunetti-Pierri N, Ng T, Iannitti D, Cioffi W, Stapleton G, Law M, Breinholt J, Palmer D, Grove N, Rice K, Bauer C, Finegold M, Beaudet A, Mullins C, Ng P (2013) Transgene 
expression up to 7 years in nonhuman primates following hepatic transduction with helper-dependent adenoviral vectors. Hum Gene Ther 24(8):761-765. doi:10.1089/ hum.2013.071

84. Gubrij IB, Martin SR, Pangle AK, Kurten R, Johnson LG (2014) Attenuation of monocrotaline-induced pulmonary hypertension by luminal adeno-associated virus serotype 9 gene transfer of prostacyclin synthase. Hum Gene Ther 25(6):498-505. doi:10.1089/hum.2013.187

85. Kim J-D, Lee A, Choi J, Park Y, Kang H, Chang W, Lee M-S, Kim J (2015) Epigenetic modulation as a therapeutic approach for pulmonary arterial hypertension. Exp Mol Med 47:e175. doi:10.1038/emm.2015.45

86. Xu X-F, Cheng F, Du L-Z (2011) Epigenetic regulation of pulmonary arterial hypertension. Hypertens Res 34(9):981986. doi:10.1038/hr.2011.79

87. Gurha P (2016) MicroRNAs in cardiovascular disease. Curr Opin Cardiol. doi:10.1097/hco.0000000000000280

88. Welten SMJ, Goossens EAC, Quax PHA, Nossent AY (2016) The multifactorial nature of microRNAs in vascular remodelling. Cardiovasc Res. doi:10.1093/cvr/cvw039

89. Kurakula K, Goumans M-J, Ten Dijke P (2015) Regulatory RNAs controlling vascular (dys)function by affecting TGF- $\beta$ family signalling. EXCLI J 14:832-850. doi:10.17179/ excli2015-423

90. Courboulin A, Ranchoux B, Cohen-Kaminsky S, Perros F, Bonnet S (2016) MicroRNA networks in pulmonary arterial hypertension: share mechanisms with cancer? Curr Opin Oncol 28(1):72-82. doi:10.1097/cco.0000000000000253

91. Gupta S, Li L (2015) Modulation of miRNAs in pulmonary hypertension. Int J Hypertens 2015:169069. doi:10.1155/2015/169069

92. Weiler J, Hunziker J, Hall J (2006) Anti-miRNA oligonucleotides (AMOs): ammunition to target miRNAs implicated in human disease?. Gene Ther 13(6):496-502. doi:10.1038/ sj.gt. 3302654

93. Gubrij IB, Pangle AK, Pang L, Johnson LG (2016) Reversal of microrna dysregulation in an animal model of pulmonary hypertension. PLoS ONE 11(1):e0147827. doi:10.1371/journal.pone. 0147827

94. Courboulin A, Paulin R, Giguère NJ, Saksouk N, Perreault T, Meloche J, Paquet ER, Biardel S, Provencher S, Côté J, Simard MJ, Bonnet S (2011) Role for miR-204 in human pulmonary arterial hypertension. J Exp Med 208(3):535-548. doi:10.1084/jem.20101812

95. Bienertova-Vasku J, Novak J, Vasku A (2015) MicroRNAs in pulmonary arterial hypertension: pathogenesis, diagnosis and treatment. J Am Soc Hypertens 9(3):221-234. doi:10.1016/j. jash.2014.12.011

96. Fujita Y, Takeshita F, Kuwano K, Ochiya T (2013) RNAi therapeutic platforms for lung diseases. Pharmaceuticals 6(2):223-250. doi:10.3390/ph6020223

97. Comer BS, Ba M, Singer CA, Gerthoffer WT (2015) Epigenetic targets for novel therapies of lung diseases. Pharmacol Ther 147:91-110. doi:10.1016/j.pharmthera.2014.11.006

98. Zhang Y, Wang Z, Gemeinhart RA (2013) Progress in microRNA delivery. J Control Release 172(3):962-974. doi:10.1016/j.jconrel.2013.09.015

99. Bobbin ML, Rossi JJ (2016) RNA interference (RNAi)based therapeutics: delivering on the promise? Annu Rev Pharmacol Toxicol 56:103-122. doi:10.1146/ annurev-pharmtox-010715-103633

100. González CI, Bhattacharya A, Wang W, Peltz SW (2001) Nonsense-mediated mRNA decay in Saccharomyces cerevisiae. Gene 274(1-2):15-25
101. Maquat LE (2004) Nonsense-mediated mRNA decay: splicing, translation and mRNP dynamics. Nat Rev Mol Cell Biol 5(2):89-99. doi:10.1038/nrm1310

102. Noensie EN, Dietz HC (2001) A strategy for disease gene identification through nonsense-mediated mRNA decay inhibition. Nat Biotechnol 19(5):434-439. doi:10.1038/88099

103. Howard M, Frizzell RA, Bedwell DM (1996) Aminoglycoside antibiotics restore CFTR function by overcoming premature stop mutations. Nat Med 2(4):467-469

104. Barton-Davis ER, Cordier L, Shoturma DI, Leland SE, Sweeney HL (1999) Aminoglycoside antibiotics restore dystrophin function to skeletal muscles of $\mathrm{mdx}$ mice. J Clin Invest 104(4):375-381. doi:10.1172/jci7866

105. Diop D, Chauvin C, Jean-Jean O (2007) Aminoglycosides and other factors promoting stop codon readthrough in human cells. C R Biol 330(1):71-79. doi:10.1016/j.crvi.2006.09.001

106. Kuzmiak HA, Maquat LE (2006) Applying nonsense-mediated mRNA decay research to the clinic: progress and challenges. Trends Mol Med 12(7):306-316. doi:10.1016/j molmed.2006.05.005

107. Hermann T (2007) Aminoglycoside antibiotics: old drugs and new therapeutic approaches. Cell Mol Life Sci 64(14):18411852. doi:10.1007/s00018-007-7034-x

108. Zingman LV, Park S, Olson TM, Alekseev AE, Terzic A (2007) Aminoglycoside-induced translational read-through in disease: overcoming nonsense mutations by pharmacogenetic therapy. Clin Pharmacol Ther 81(1):99-103. doi:10.1038/ sj.clpt.6100012

109. Kellermayer R (2006) Translational readthrough induction of pathogenic nonsense mutations. Eur J Med Genet 49(6):445450. doi:10.1016/j.ejmg.2006.04.003

110. Kulyté A, Dryselius R, Karlsson J, Good L (2005) Gene selective suppression of nonsense termination using antisense agents. Biochim Biophys Acta 1730(3):165-172. doi:10.1016/j. bbaexp.2005.07.004

111. Linde L, Kerem B (2008) Introducing sense into nonsense in treatments of human genetic diseases. Trends Genet 24(11):552-563. doi:10.1016/j.tig.2008.08.010

112. Namy O, Hatin I, Rousset JP (2001) Impact of the six nucleotides downstream of the stop codon on translation termination. EMBO Rep 2(9):787-793. doi:10.1093/embo-reports/kve176

113. Nasim MT, Ghouri A, Patel B, James V, Rudarakanchana N, Morrell NW, Trembath RC (2008) Stoichiometric imbalance in the receptor complex contributes to dysfunctional BMPR-II mediated signalling in pulmonary arterial hypertension. Hum Mol Genet 17(11):1683-1694. doi:10.1093/hmg/ddn059

114. Hamid R, Hedges LK, Austin E, Phillips JA, Loyd JE, Cogan JD (2010) Transcripts from a novel BMPR2 termination mutation escape nonsense mediated decay by downstream translation re-initiation: implications for treating pulmonary hypertension. Clin Genet 77(3):280-286. doi:10.1111/j.1399-0004.2009.01311.x

115. Ryan NJ (2014) Ataluren: first global approval. Drugs 74(14):1709-1714. doi:10.1007/s40265-014-0287-4

116. Rudarakanchana N, Flanagan JA, Chen H, Upton PD, Machado R, Patel D, Trembath RC, Morrell NW (2002) Functional analysis of bone morphogenetic protein type II receptor mutations underlying primary pulmonary hypertension. Hum Mol Genet 11(13):1517-1525

117. Rubenstein RC, Egan ME, Zeitlin PL (1997) In vitro pharmacologic restoration of CFTR-mediated chloride transport with sodium 4-phenylbutyrate in cystic fibrosis epithelial cells containing delta F508-CFTR. J Clin Invest 100(10):2457-2465. doi: $10.1172 /$ jci1 19788

118. Rubenstein RC, Zeitlin PL (1998) A pilot clinical trial of oral sodium 4-phenylbutyrate (Buphenyl) in deltaF508-homozygous 
cystic fibrosis patients: partial restoration of nasal epithelial CFTR function. Am J Respir Crit Care Med 157(2):484-490. doi:10.1164/ajrccm.157.2.9706088

119. Rubenstein RC, Zeitlin PL (2000) Sodium 4-phenylbutyrate downregulates Hsc70: implications for intracellular trafficking of DeltaF508-CFTR. Am J Physiol Cell Physiol 278(2):C259-C267

120. Rubenstein RC, Lyons BM (2001) Sodium 4-phenylbutyrate downregulates HSC70 expression by facilitating mRNA degradation. Am J Physiol Lung Cell Mol Physiol 281(1):L43-L51

121. Zhang X-M, Wang X-T, Yue H, Leung SW, Thibodeau PH, Thomas PJ, Guggino SE (2003) Organic solutes rescue the functional defect in delta F508 cystic fibrosis transmembrane conductance regulator. J Biol Chem 278(51):51232-51242. doi:10.1074/jbc.M309076200

122. Papp E, Csermely P (2006) Chemical chaperones: mechanisms of action and potential use. Handb Exp Pharmacol 172:405-416

123. Ma L, Liu Y, El-Achkar TM, Wu X-R (2012) Molecular and cellular effects of Tamm-Horsfall protein mutations and their rescue by chemical chaperones. J Biol Chem 287(2):12901305. doi:10.1074/jbc.M111.283036

124. Hua Y, Kandadi MR, Zhu M, Ren J, Sreejayan N (2010) Tauroursodeoxycholic acid attenuates lipid accumulation in endoplasmic reticulum-stressed macrophages. J Cardiovasc Pharmacol 55(1):49-55. doi:10.1097/FJC.0b013e3181c37d86

125. da-Silva WS, Ribich S, Arrojo e Drigo R, Castillo M, Patti M-E, Bianco AC (2011) The chemical chaperones tauroursodeoxycholic and 4-phenylbutyric acid accelerate thyroid hormone activation and energy expenditure. FEBS Lett 585(3):539-544. doi:10.1016/j.febslet.2010.12.044

126. Cao SS, Zimmermann EM, Chuang B-M, Song B, Nwokoye A, Wilkinson JE, Eaton KA, Kaufman RJ (2013) The unfolded protein response and chemical chaperones reduce protein misfolding and colitis in mice. Gastroenterology 144(5):989-1000. e1006. doi:10.1053/j.gastro.2013.01.023

127. Sobolewski A, Rudarakanchana N, Upton PD, Yang J, Crilley TK, Trembath RC, Morrell NW (2008) Failure of bone morphogenetic protein receptor trafficking in pulmonary arterial hypertension: potential for rescue. Hum Mol Genet 17(20):3180 3190. doi:10.1093/hmg/ddn214

128. Yang Y-M, Lane KB, Sehgal PB (2013) Subcellular mechanisms in pulmonary arterial hypertension: combinatorial modalities that inhibit anterograde trafficking and cause bone morphogenetic protein receptor type 2 mislocalization. Pulm Circ 3(3):533-550. doi:10.1086/674336

129. Frump AL, Lowery JW, Hamid R, Austin ED, de Caestecker M (2013) Abnormal trafficking of endogenously expressed BMPR2 mutant allelic products in patients with heritable pulmonary arterial hypertension. PLoS ONE 8(11):e80319. doi:10.1371/journal.pone.0080319

130. Zeitlin PL, Diener-West M, Rubenstein RC, Boyle MP, Lee CKK, Brass-Ernst L (2002) Evidence of CFTR function in cystic fibrosis after systemic administration of 4-phenylbutyrate. Mol Ther 6(1):119-126. doi:10.1006/mthe.2002.0639

131. Obici L, Cortese A, Lozza A, Lucchetti J, Gobbi M, Palladini G, Perlini S, Saraiva MJ, Merlini G (2012) Doxycycline plus tauroursodeoxycholic acid for transthyretin amyloidosis: a phase II study. Amyloid 19(Suppl 1):34-36. doi:10.3109/1350 6129.2012.678508

132. Berry GT, Steiner RD (2001) Long-term management of patients with urea cycle disorders. J Pediatr 138(1 Suppl):S56-60; discussion S60-51

133. Iannitti T, Palmieri B (2011) Clinical and experimental applications of sodium phenylbutyrate. Drugs R D 11(3):227-249. doi:10.2165/11591280-000000000-00000
134. Durrington HJ, Upton PD, Hoer S, Boname J, Dunmore BJ, Yang J, Crilley TK, Butler LM, Blackbourn DJ, Nash GB, Lehner PJ, Morrell NW (2010) Identification of a lysosomal pathway regulating degradation of the bone morphogenetic protein receptor type II. J Biol Chem 285(48):37641-37649. doi:10.1074/jbc.M110.132415

135. Satow R, Kurisaki A, Chan T-c, Hamazaki TS, Asashima M (2006) Dullard promotes degradation and dephosphorylation of BMP receptors and is required for neural induction. Dev Cell 11(6):763-774. doi:10.1016/j.devcel.2006.10.001

136. Luzio JP, Pryor PR, Bright NA (2007) Lysosomes: fusion and function. Nat Rev Mol Cell Biol 8(8):622-632. doi:10.1038/ nrm2217

137. Wertz JW, Bauer PM (2008) Caveolin-1 regulates BMPRII localization and signaling in vascular smooth muscle cells. Biochem Biophys Res Commun 375(4):557-561. doi:10.1016/j. bbrc.2008.08.066

138. Hartung A, Bitton-Worms K, Rechtman MM, Wenzel V, Boergermann JH, Hassel S, Henis YI, Knaus P (2006) Different routes of bone morphogenic protein (BMP) receptor endocytosis influence BMP signaling. Mol Cell Biol 26(20):7791-7805. doi: $10.1128 / \mathrm{mcb} .00022-06$

139. Di Guglielmo GM, Le Roy C, Goodfellow AF, Wrana JL (2003) Distinct endocytic pathways regulate TGF-beta receptor signalling and turnover. Nat Cell Biol 5(5):410-421. doi:10.1038/ ncb975

140. Zaidi SH, You XM, Ciura S, O'Blenes S, Husain M, Rabinovitch M (2000) Suppressed smooth muscle proliferation and inflammatory cell invasion after arterial injury in elafin-overexpressing mice. J Clin Invest 105(12):1687-1695. doi:10.1172/ jci9147

141. Zaidi SHE, You X-M, Ciura S, Husain M, Rabinovitch M (2002) Overexpression of the serine elastase inhibitor elafin protects transgenic mice from hypoxic pulmonary hypertension. Circulation 105(4):516-521

142. Cowan KN, Heilbut A, Humpl T, Lam C, Ito S, Rabinovitch M (2000) Complete reversal of fatal pulmonary hypertension in rats by a serine elastase inhibitor. Nat Med 6(6):698-702. doi: $10.1038 / 76282$

143. Alam SR, Lewis SC, Zamvar V, Pessotto R, Dweck MR, Krishan A, Goodman K, Oatey K, Harkess R, Milne L, Thomas S, Mills NM, Moore C, Semple S, Wiedow O, Stirrat C, Mirsadraee S, Newby DE, Henriksen PA (2015) Perioperative elafin for ischaemia-reperfusion injury during coronary artery bypass graft surgery: a randomised-controlled trial. Heart 101(20):1639-1645. doi:10.1136/heartjnl-2015-307745

144. Hubbard VM, Valdor R, Macian F, Cuervo AM (2012) Selective autophagy in the maintenance of cellular homeostasis in aging organisms. Biogerontology 13(1):21-35. doi:10.1007/ s10522-011-9331-X

145. Kroemer G, Marino G, Levine B (2010) Autophagy and the integrated stress response. Mol Cell 40(2):280-293. doi:10.1016/j.molcel.2010.09.023

146. Long L, Yang X, Southwood M, Lu J, Marciniak SJ, Dunmore BJ, Morrell NW (2013) Chloroquine prevents progression of experimental pulmonary hypertension via inhibition of autophagy and lysosomal bone morphogenetic protein type II receptor degradation. Circ Res 112(8):1159-1170. doi:10.1161/ CIRCRESAHA.111.300483

147. Daniel JK, Fabio CA, Hagai A et al (2012) Guidelines for the use and interpretation of assays for monitoring autophagy. Autophagy 8:445-544. doi:10.1080/15548627.2015.1100356

148. Ben-Zvi I, Kivity S, Langevitz P, Shoenfeld Y (2012) Hydroxychloroquine: from malaria to autoimmunity. Clin Rev Allergy Immunol 42(2):145-153. doi:10.1007/s12016-010-8243-x 
149. Rabinovitch M, Guignabert C, Humbert M, Nicolls MR (2014) Inflammation and immunity in the pathogenesis of pulmonary arterial hypertension. Circ Res 115(1):165-175. doi:10.1161/ CIRCRESAHA.113.301141

150. Ormiston ML, Upton PD, Li W, Morrell NW (2015) The promise of recombinant BMP ligands and other approaches targeting BMPR-II in the treatment of pulmonary arterial hypertension. Glob Cardiol Sci Pract 2015(4):47. doi:10.5339/gcsp.2015.47

151. Cheng H, Jiang W, Phillips FM, Haydon RC, Peng Y, Zhou L, Luu HH, An N, Breyer B, Vanichakarn P, Szatkowski JP, Park JY, He TC (2003) Osteogenic activity of the fourteen types of human bone morphogenetic proteins (BMPs). J Bone Joint Surg Am 85:1544-1552

152. Croom KF, Curran MP (2008) Sildenafil: a review of its use in pulmonary arterial hypertension. Drugs 68(3):383-397

153. Ito T, Ozawa K, Shimada K (2007) Current drug targets and future therapy of pulmonary arterial hypertension. Curr Med Chem 14(6):719-733

154. Zhao L, Sebkhi A, Ali O, Wojciak-Stothard B, Mamanova L, Yang Q, Wharton J, Wilkins MR (2009) Simvastatin and sildenafil combine to attenuate pulmonary hypertension. Eur Respir J 34(4):948-957. doi:10.1183/09031936.00143508

155. Barnett CF, Machado RF (2006) Sildenafil in the treatment of pulmonary hypertension. Vasc Health Risk Manag 2(4):411-422

156. Schwappacher R, Weiske J, Heining E, Ezerski V, Marom B, Henis YI, Huber O, Knaus P (2009) Novel crosstalk to BMP signalling: cGMP-dependent kinase I modulates BMP receptor and Smad activity. EMBO J 28(11):1537-1550. doi:10.1038/ emboj.2009.103

157. Long L, Crosby A, Yang X, Southwood M, Upton PD, Kim D-K, Morrell NW (2009) Altered bone morphogenetic protein and transforming growth factor-beta signaling in rat models of pulmonary hypertension: potential for activin receptor-like kinase-5 inhibition in prevention and progression of disease. Circulation 119(4):566-576. doi:10.1161/ circulationaha.108.821504

158. Yang J, Li X, Al-Lamki RS, Wu C, Weiss A, Berk J, Schermuly RT, Morrell NW (2013) Sildenafil potentiates bone morphogenetic protein signaling in pulmonary arterial smooth muscle cells and in experimental pulmonary hypertension. Arterioscler Thromb Vasc Biol 33(1):34-42. doi:10.1161/ atvbaha.112.300121

159. Wang R-C, Jiang F-M, Zheng Q-1, Li C-T, Peng X-Y, He C-Y, Luo J, Liang Z-A (2014) Efficacy and safety of sildenafil treatment in pulmonary arterial hypertension: a systematic review. Respir Med 108(3):531-537. doi:10.1016/j.rmed.2014.01.003

160. Spiekerkoetter E, Tian X, Cai J, Hopper RK, Sudheendra D, Li CG, El-Bizri N, Sawada H, Haghighat R, Chan R, Haghighat L, de Jesus Perez V, Wang L, Reddy S, Zhao M, Bernstein
D, Solow-Cordero DE, Beachy PA, Wandless TJ, Ten Dijke P, Rabinovitch M (2013) FK506 activates BMPR2, rescues endothelial dysfunction, and reverses pulmonary hypertension. J Clin Invest 123(8):3600-3613. doi:10.1172/jci65592

161. Wu X, Wang L, Han Y, Regan N, Li P-K, Villalona MA, Hu X, Briesewitz R, Pei D (2011) Creating diverse target-binding surfaces on FKBP12: synthesis and evaluation of a rapamycin analogue library. ACS Comb Sci 13(5):486-495. doi:10.1021/ co200057n

162. Albiñana V, Sanz-Rodríguez F, Recio-Poveda L, Bernabéu C, Botella LM (2011) Immunosuppressor FK506 increases endoglin and activin receptor-like kinase 1 expression and modulates transforming growth factor- $\beta 1$ signaling in endothelial cells. Mol Pharmacol 79(5):833-843. doi:10.1124/mol.110.067447

163. Spiekerkoetter E, Sung YK, Sudheendra D, Bill M, Aldred MA, van de Veerdonk MC, Vonk Noordegraaf A, Long-Boyle J, Dash R, Yang PC, Lawrie A, Swift AJ, Rabinovitch M, Zamanian RT (2015) Low-dose FK506 (Tacrolimus) in end-stage pulmonary arterial hypertension. Am J Respir Crit Care Med 192(2):254-257. doi:10.1164/rccm.201411-2061LE

164. Plosker GL, Foster RH (2000) Tacrolimus: a further update of its pharmacology and therapeutic use in the management of organ transplantation. Drugs 59(2):323-389

165. Takeda Y, Miyamori I, Furukawa K, Inaba S, Mabuchi $H$ (1999) Mechanisms of FK 506-induced hypertension in the rat. Hypertension 33(1):130-136

166. Drake KM, Dunmore BJ, McNelly LN, Morrell NW, Aldred MA (2013) Correction of nonsense BMPR2 and SMAD9 mutations by ataluren in pulmonary arterial hypertension. Am J Respir Cell Mol Biol 49(3):403-409. doi:10.1165/ rcmb.2013-0100OC

167. Bloom RD, Reese PP (2007) Chronic kidney disease after nonrenal solid-organ transplantation. J Am Soc Nephrol 18(12):3031-3041. doi:10.1681/asn.2007040394

168. Randhawa PS, Starzl TE, Demetris AJ (1997) Tacrolimus (FK506)-associated renal pathology. Adv Anat Pathol $4(4): 256-276$

169. Endo-Takahashi Y, Negishi Y, Nakamura A, Ukai S, Ooaku K, Oda Y, Sugimoto K, Moriyasu F, Takagi N, Suzuki R, Maruyama K, Aramaki Y (2014) Systemic delivery of miR-126 by miRNA-loaded bubble liposomes for the treatment of hindlimb ischemia. Sci Rep 4:3883. doi:10.1038/srep03883

170. D'Astolfo DS, Pagliero RJ, Pras A, Karthaus WR, Clevers H, Prasad V, Lebbink RJ, Rehmann H, Geijsen N (2015) Efficient intracellular delivery of native proteins. Cell 161(3):674-690. doi:10.1016/j.cell.2015.03.028

171. Esch EW, Bahinski A, Huh D (2015) Organs-on-chips at the frontiers of drug discovery. Nat Rev Drug Discov 14(4):248260. doi:10.1038/nrd4539 